\title{
12. LIMALOK GUYOT: DEPOSITIONAL HISTORY OF THE CARBONATE PLATFORM FROM DOWNHOLE LOGS AT SITE 871 (LAGOON) ${ }^{1}$
}

\author{
James G. Ogg, ${ }^{2}$ Gilbert F. Camoin, ${ }^{3}$ and Annie Arnaud Vanneau ${ }^{4}$
}

\begin{abstract}
The late Paleocene-middle Eocene platform succession at Site 871 displays four main depositional cycles, culminating in a two-stage final drowning. Sedimentation between each pair of episodes generally consists of a deep-water phase followed by a shoaling into sets of upward-shallowing algal- or microbial-rich parasequences. Some of the parasequences terminate in surfaces of emergence. The thicker depositional cycles also encompass two or more minor episodes of shallowing and deepening.

After the initial submergence of the weathered volcanic edifice and an accumulation of algal-rich facies, the upper Paleocene platform succession has a cycle of a protected-lagoon phase followed by an upward shoaling and possible brief emergence. Near the Paleocene/Eocene stage boundary, a second major deepening established a lagoon with episodes of storm reworking. This lower Eocene lagoon facies contains a secondary cycle of shoaling and deepening. Peritidal to emergent conditions were established near the end of the early Eocene by a fall in relative sea levels. This shallow-water facies is terminated by a major transgressive deepening followed by a thin upward-shoaling cycle and brief return to a shallow-water facies. A second major, transgressive pulse permanently drowns the shallow-water platform.

The five main deepening events recorded in the Limalok carbonate platform at Site 871 appear to coincide with five major late Paleocene to earliest middle Eocene transgressions recognized on continental margins. The timing of each major transgressive episodes is consistent with a steady seamount subsidence rate of $27 \mathrm{~m} / \mathrm{m}$.y. The stratigraphy of the final stages of the platform at Site 871 , coupled with the correlation to the eustatic sea-level curve, suggests that the main requirement for guyot drowning is a major eustatic sea-level fall and extended lowstand followed by a rapid major transgressive deepening. However, there appear to be other environmental factors associated with a near-equatorial setting during the middle Eocene that inhibited the ability of the carbonate platform to keep pace with a major eustatic sea-level rise.
\end{abstract}

\section{OVERVIEW}

Site 871 was positioned to penetrate "lagoonal" sediments of the carbonate platform on Limalok (formerly "Harrie") Guyot at $5.6^{\circ} \mathrm{N}$, $172.3^{\circ} \mathrm{E}$ in the southern Marshall Islands (see site map preceding title page). Hole $871 \mathrm{C}$ penetrated approximately $300 \mathrm{~m}$ of carbonate platform carbonates overlying the volcanic edifice. The top of the platform succession is overlain by $100 \mathrm{~m}$ of pelagic oozes. A basal transgressive marine deposit of early late Paleocene, nannofossil-bearing, organic-rich claystone overlies subaerially weathered basalts. The initial platform facies of late Paleocene age is dominated by bioclasticrich grainstones characteristic of open-marine to "back-reef" conditions. In contrast, the overlying lower to middle Eocene lime-mudrich facies indicates formation of a protected shallow lagoon. Various lagoonal-type environments continued until the final platform drowning. The Limalok Guyot carbonate platform is overlain by an ironmanganese oxide and phosphatic crust that incorporates middle Eocene calcareous plankton and contains borings infilled with early Oligocene microfossils. Pelagic sediment accumulation did not begin on this submerged surface until the early Miocene.

Integration of logging data and cored lithologies enable a detailed analysis of this general facies development (Fig. 1, back pocket). Logs of different physical parameters, such as resistivity, density, and natural gamma-ray intensity, supplemented by Formation MicroScanner (FMS) imagery indicate a complex stratigraphy of varying grain sizes and cementation. These physical properties and lithologic data have been merged into a meter-by-meter physical lithology column with

\footnotetext{
${ }^{1}$ Haggerty, J.A., Premoli Silva, I., Rack, F., and McNutt, M.K. (Eds.), 1995. Proc. ODP, Sci. Results, 144: College Station, TX (Ocean Drilling Program).

${ }^{2}$ Department of Earth and Atmospheric Sciences, Purdue University, West Lafayette, IN 47907, U.S.A.

${ }^{3}$ Centre de Sédimentologie et Paléontologie, URA 1208 du CNRS, Université de Provence, 3 Place Victor Hugo, F-13331 Marseille Cedex 3, France.

${ }^{4}$ Institut Dolomieu, Université de Grenoble, Rue Maurice Gignoux, F-38031 Grenoble Cedex, France.
}

associated interpretations of depositional environments and identification of possible sea-level trends. Four main depositional cycles or sequences of transgressive deepening through progradational shallowing could be identified in the carbonate platform succession.

\section{INTRODUCTION AND PROCEDURE FOR FACIES ANALYSIS}

A full suite of geophysical, geochemical, and FMS tools were run from the bottom of the suspended drill pipe at 118.7 meters below seafloor (mbsf) to the base of the carbonate platform facies at 425.7 mbsf. The tool strings were not lowered further to avoid possible problems with sticking within the underlying clay-rich zone above the basalt substrate. The total depth penetration by each tool varies because of the placement of different tools on the strings, and the base of the carbonate platform was not recorded by most of the logging tools.

Core recovery within the $289 \mathrm{~m}$ of platform carbonates in Hole $871 \mathrm{C}$ averaged only $3.5 \%$. Therefore, these logs are invaluable for interpreting the facies succession and sea-level fluctuations within the carbonate platform. In particular, the high-resolution microresistivity borehole-wall imagery from the FMS tool is excellent for determining the thickness and vertical succession of lithologies displaying similar "resistivity textures," which, in turn, can be interpreted as specific carbonate facies.

The procedure for interpreting the depositional history of Site 871 from the combination of core recovery and downhole logs consists of the following steps.

1. Depths of logging runs are calibrated to each other and related to coring depths. The FMS logs are graphically displayed in various formats and scales for visual interpretation of resistivity features. The geochemical logs are processed to obtain realistic relative fluctuations of each element.

2. Distinct carbonate facies recovered in cores are compared with the logging data to obtain a characteristic logging "signature" so that we can recognize these facies in intervals where core recovery was 
sparse. This "ground-truth" calibration was especially important for the FMS resistivity imagery.

3. A composite description of logging features and associated core recovery is made of the hole, which incorporates preliminary interpretation of the vertical succession of facies. The array of highresolution logging data enabled suites of lithologic subunits to be defined and parasequence trends to be distinguished.

4. The facies succession is interpreted in terms of shifting depositional environments and relative sea-level fluctuations. At each level of this chain of interpretations, various assumptions and models need to be incorporated; we will make an effort to clarify most of these steps.

\section{CALIBRATION AND PROCESSING OF KEY LOGS Depth Shifting}

Logging data is initially collected relative to the meters of logging wire suspended below the drill rig floor and adjusted for the spacing of tools on the particular tool string. However, this initial array of data generally does not correspond to the cored intervals within the hole, as measured by the lowered pipe during drilling operations. There are several factors that contribute to this mismatch, and a series of calibrations must be made: first to the position of the drill pipe, then between the different logs. Because of the very poor recovery throughout Hole $871 \mathrm{C}$ and the inability to uniquely assign any of the few pieces of lithology to the detailed borehole logging, we have used the compensated logging depths of the FMS tools as the standard for all descriptions and depths of features, rather than the "educated guesses" made by the shipboard party. Therefore, it is important to summarize how these depths were derived.

The drill pipe during the logging runs is at a known depth below the dual-elevator stool on the rig floor (in turn, $10.9 \mathrm{~m}$ above mean sea level during the Site 879 drilling), and all cores were drilled with respect to this same reference. The initial contact of the drill string with the seafloor ("bottom felt depth") is then used to convert drilling depths to "meters below seafloor" (mbsf). This "bottom felt depth" was 1265.5 "meters below rig floor" (mbrf) for Hole 879A, implying that the seafloor was 1254.6 "meters below sea level" (mbsl). Therefore, the drill depths of cores (mbrf) were converted into depth within Hole 879A (mbsf) by subtracting $1265.5 \mathrm{~m}$ (Shipboard Scientific Party, 1993).

The different logging runs have varying degrees of stretch of the wireline. Therefore, a natural gamma tool (NGT) is part of each logging tool string, and distinctive natural gamma peaks within the rock succession are used to depth shift each log with respect to a standard run. The different logging records were later interactively depth shifted by the Lamont-Doherty Earth Observatory Borehole Research Group (Lamont-BRG) with reference to the natural gammaray record from the geochemical run (ACT/GST/NGT) and to the depth of the seafloor. Key features on the inter-log NGT records are at nearly identical depths among the various runs.

Calibration of the logging depth scale (meters of wireline below the rig floor) to the drill core record was accomplished by Lamont-BRG by identifying the base of the suspended drill pipe (mbrf) in the response of the resistivity logs. During all logging runs in Hole 871C, the drill pipe was suspended at $1384.2 \mathrm{mbrf}$, or $118.7 \mathrm{~m}$ below the $1265.5 \mathrm{~m}$ "bottom felt depth" used to assign core depths, implying that it was $118.7 \mathrm{~m}$ into Hole $879 \mathrm{~A}$. However, the response of the resistivity logs was interpreted by Lamont-BRG to indicate an apparent depth of the drill-pipe base at $1264.0 \mathrm{mbrf}$, which was $1.5 \mathrm{~m}$ higher than its actual depth. Therefore, Lamont-BRG applied a depth correction of $1264.0 \mathrm{~m}$, instead of $1265.5 \mathrm{~m}$, to convert mbrf of the wireline logging depths of all logs to mbsf within the drill hole. It is important to note that this new depth correction by Lamont-BRG requires that an average of $0.7 \mathrm{~m}$ be added to the depths of logging features cited in the downhole discussions in the Site 871 chapter of Volume 144 Initial Reports (Premoli Silva, Haggerty, Rack, et al., 1993).

There are additional complications, such as deducing the exact base of the drill pipe in the logging runs or identifying unique sharp features on the natural gamma traces for precise depth shifting. As a result, the independent depth calibration of the logs made by the shipboard logging team and by the Lamont-BRG differ by approximately $0.7 \mathrm{~m}$. In addition, the Lamont-BRG internally adjusts the two FMS runs with respect to each other to match common features to within a few centimeters. This internal depth shifting of FMS traces is thought to be necessary because of differential stretching of the wireline during ocean swells or variable friction within the borehole.

In this summary of logging stratigraphy, all features are described relative to "corrected" FMS depths processed by Lamont-BRG, which are the scales for the FMS imagery on the well-log data compact disk (CD-ROM) distributed with the Ocean Drilling Program Initial Reports (Premoli Silva, Haggerty, Rack, et al., 1993).

This suite of Lamont-BRG depth adjustments to the FMS runs causes a variance with the depth-corrected scales for the geophysics and geochemistry logging suites, and position of features may possibly be slightly different from coring depths of recovered sediments. In general, the FMS features are approximately $2.0 \mathrm{~m}$ below the depth of the same feature in the geophysics logs within most of the borehole, and $2.5-3.0 \mathrm{~m}$ below the resistivity $\log$ in the lower logged interval of 415-420 mbsf. Therefore, because the Lamont-BRG FMS depths are the distributed archive version for FMS features, we have depth shifted the resistivity and geochemical logging data downward by approximately $2 \mathrm{~m}$ for the display of the combined log-core interpretations shown in the accompanying diagrams. Other sharp features in the FMS and in the resistivity logs support this general depth correction, although minor "tuning" of $10-30 \mathrm{~cm}$ was required in some intervals to further place the resistivity log into a more exact correspondence with the FMS log. The natural gamma-ray record used in the accompanying diagrams for Site 871 is from the NGT on the same FMS string, so its depths should be consistent with depths of the FMS imagery processed by Lamont-BRG. In the few instances where cored lithologic features appear to be at variance in depth with the corresponding FMS features, we note the calibration problem in the descriptions.

Regardless of the exact calibration of the various "corrected" depths, the thicknesses and spacing of all features will be identical among the borehole, the FMS imagery, and the other downhole logs.

\section{Processing of FMS Resistivity Imagery}

The FMS tool creates high-resolution images of the borehole by measuring the electrical resistivity contrast across an array of small electrodes (Ekstrom et al., 1986; Pezard and Luthi, 1988; Bourke et al., 1989). FMS imagery has been applied in the petroleum industry since 1986, but it had been previously precluded from use by the Ocean Drilling Program (ODP) because of constraints imposed by the internal diameter (about $10 \mathrm{~cm}$ ) of the drill pipe. A modified sensor was consequently developed by Schlumberger for ODP and was first deployed during Leg 126 in the western Pacific (Pezard et al., 1990).

The ODP FMS has four orthogonal pads containing 16 padmounted button electrodes that are pressed against the borehole. The resolution of the ODP FMS images is improved by using a smaller size of the electrode arrays than is common for the commercial FMS tool. The FMS records an array of current intensity or conductance measurements every $0.25 \mathrm{~cm}$ and has a vertical resolution of approximately $1 \mathrm{~cm}$. In contrast, typical conventional downhole measurements are sampled only every $15 \mathrm{~cm}$ and generally have a resolution of approximately $60 \mathrm{~cm}$; thus, the sampling rate and resolution of the FMS is 60 times finer than for most other logging devices. This finescale resolution allows detailed study of subsurface structures and bedding characteristics.

The electrode currents probe the conductivity to a depth of a few centimeters into the borehole wall and respond to variations in electrolytic conduction or in cation exchange on the surfaces of clays and other conductive minerals (Bourke et al., 1989). The conductivity traces are presented as microresistivity, although the FMS does not provide a direct quantitative value of formation resistivity. Variations 
on these resistivity images reflect changing physical and chemical properties of the rock (such as porosity, mineralogy, cementation, and grain size) and of the interstitial fluid.

The four orthogonal sets of 16 adjacent traces are coded into either a gray-scale or a color image. In gray-scale images of this log of relative resistivity, white represents the most resistive values and black the least resistive ones. Magnetometers in the FMS tool string enable orientation of the set of images relative to the north magnetic field, thereby enabling relative alignment of multiple traces made during separate runs and determination of the orientation of dips and sedimentary structures. A single run of the ODP FMS provides approximately $25 \%$ coverage of the borehole circumference. Two runs were made in Hole $874 \mathrm{~B}$ to enable a maximum of $50 \%$ coverage of the borehole where traces did not overlap.

Calipers on the FMS tool provide precise measurements of borehole diameter in two orthogonal directions. The tool string also includes a 3-axis accelerometer for recording variations in vertical speed that are incorporated in computing FMS pad positions within the borehole. This speed correction procedure is very important in ODP logging operations as the sampling intervals can be disturbed by the heave effect of ocean surface waves on the wireline.

The FMS measurements undergo a series of processing steps that adjust the traces for irregular tool movements, fluctuating operating voltages, and response of individual electrodes. The traces are then converted into enhanced images of the borehole (see appendix in Molinie and Ogg, 1992a, 1992b). The desired type of interpretation influences the window dimensions over which resistivity images are normalized and the techniques of enhancement. The examples of FMS images reproduced in the figures in our report have been "static mode" processed over the entire 296-m interval logged by the FMS in Hole $871 \mathrm{C}$, implying that the 16 shades of gray have been linearly normalized between the highest value of resistivity (white) to the lowest value (black) occurring within that interval. Within this window, a particular shade of gray corresponds to the same relative resistivity, but that resistivity level may be represented by a different gray shade in the adjacent window. We also used "dynamic mode" images, in which the entire gray scale is nonlinearly applied within a sliding $1-\mathrm{m}$ window. These dynamic-mode images enhance visibility of bedding features and details of sedimentary structures.

Interpretations of sedimentological features from FMS images have varying degrees of reliability (Bourke et al., 1989; Harker et al., 1990). Stratigraphic contacts, bedding thicknesses and dips, slumps, crossbedding, fractures, and rock textures, such as conglomerates, can generally be unambiguously interpreted directly on the FMS imagery. Other downhole logs (such as natural gamma-ray, resistivity, porosity, and geochemical logs) are required for calibration of general compositional and textural trends. However, as noted previously, such logs do not provide the resolution of the FMS, therefore, interpretation of fine-scale compositional contrasts, diagenetic variations, and other details noted on the images requires calibration with core data.

\section{Geochemical Log Processing}

The geochemical records from the induced-gamma spectrum tool (GST) were converted by Lamont-BRG to relative elemental contributions by $\mathrm{Fe}$ (assuming an equal contribution by magnetite and hematite), $\mathrm{Ca}, \mathrm{Cl}, \mathrm{Si}, \mathrm{Su}, \mathrm{Ga}, \mathrm{Ti}$, and $\mathrm{H}$ (the last two elements were computed during processing), with corrections for hole diameter as recorded by calipers on the density tool (CALI on the HLDT) and on the FMS string (" $\mathrm{C} 1$ " and " $\mathrm{C} 2$ "). The relative ratios of these elemental factors are more useful for lithologic trends than use of the less accurate elemental values for direct computation of rock chemistry.

\section{INTERPRETATION OF CARBONATE FACIES FROM DOWNHOLE LOGS}

Our goal in analyzing the various logs is to obtain a complete record of the history of depositional environments. The major car- bonate textures and composite depositional facies, such as algalmicrobial mats, generally could be distinguished by their signatures on a combination of three logs: the spherically focused resistivity log (SFLU), which measures the absolute resistivity of the borehole wall with a vertical resolution of about $75 \mathrm{~cm}$; the FMS microresistivity imagery, which indicates the "texture" and vertical successions at a subcentimeter scale; and the NGT record of the relative intensity of uranium concentration. Use of a single type of log yielded more ambiguous interpretations. These log-facies signatures were developed from comparison of logs to intervals having good recovery of the lithologies and from application of logical relationships of carbonate depositional environments. In addition, the recovered sediments in each cored interval, although generally meager, provided important controls on the interpretation of the logging signals.

In contrast to surface exposures of carbonate platforms, the majority of the Limalok limestone cap has been only partially cemented. Insignificant overburden (maximum of $400 \mathrm{~m}$ ) and a lack of later meteoritic influence helped preserve the original granular relationships. Indeed, some grainstone intervals were observed to have no apparent cementation, which also caused very low recovery and "washouts" during drilling. Above the basal drowning surface on the underlying clay weathering zone, there was no noticeable influx of terrigenous influx; therefore, the downhole logs can be interpreted entirely in terms of pure carbonate facies.

\section{Resistivity Log}

Resistivity of carbonate textures progressively increases from grainstone to mudstone as the porosity is steadily diminished (e.g., Asquith, 1979; Dorfman et al., 1990). The recovered core material suggests that the initial texture of the limestone also influenced the degree of diagenetic cementation, with grainstones being less cemented than micritic mudstones. As a result, the corresponding responses of the resistivity and density tools are magnified by these changes in carbonate textures.

This relationship does not apply when an episode of penetrative early cementation has taken place because of possible subaerial exposure or hiatus in deposition. Such "surfaces" with underlying partial cementation are common in intervals having pronounced development of parasequences. In these cases, the shallower depth and presumably higher energy grainstone-packstone facies commonly underwent a greater degree of cementation and, therefore displays an upward increase in resistivity. This high-resistivity upper bed of a cycle is overlain by a facies of very low resistivity representing the succeeding deepening phase. Another common reversal of the usual relationship of grain size and bulk resistivity was observed when thin grainstone horizons from storm-bed winnowing or redeposition are interbedded within wackestone-packstone facies; these grainstone levels appear to be preferentially cemented during later diagenesis relative to the adjacent finer grained sediment.

\section{Natural Gamma-ray Log}

Natural gamma-ray intensity (NGT or SGR) within the carbonate platform in Hole 871C is mainly a monitor of the uranium concentration; the influx of clays with thorium or potassium are unimportant above the weathered volcanics.

Three distinct processes were observed to contribute to the variations in uranium natural gamma-ray intensity.

1. Uranium displays higher relative contentrations in algalcyanobacterial mats and oncolites because their reducing microenvironments are conducive to redox scavenging of uranium from seawater. Although this uranium concentration process is most effective for algal-cyanobacterial mats, it was also observed to be applicable to red-algal encrustations and concretions (rhodoliths).

2. Uranium is often enriched in limestones deposited in depositional environments in which organic matter or phosphate was origi- 
nally present, because uranium from seawater is preferentially precipitated in relatively reducing conditions (Serra, 1985). Quiet-water carbonate facies, such as wackestone and mudstone, were observed to display a higher natural gamma-ray intensity than such highenergy facies as grainstone. These mud-rich sediments, which are commonly bioturbated, probably retained a greater initial organic content in the buried sediment than the more aerated facies; therefore, uranium would be preferentially concentrated in the mud-rich facies. In this regard, minor peaks in uranium were observed to occur at levels interpreted as "maximum flooding surfaces," where the concentration of carbonate mud (and rare pelagic microfossils) and presumably fine organic material was at a maximum.

3. Uranium can be concentrated during later diagenesis at the redox interfaces between relatively oxygenated and relatively reducing interstitial water conditions. This redox enhancement was observed at the boundaries between tan- and gray-colored sediments of the same facies (such as lagoonal wackestones) and within the carbonate mud-rich transgressive sediments immediately overlying a surface of emergence or condensation. At these redox levels, the uranium was generally concentrated in a narrow horizon, in contrast to the more dispersed concentrations associated with mud- or algalcyanobacterial-rich facies.

\section{Formation MicroScanner}

The FMS imagery was important to determine the homogeneity of carbonate grains and cementation patterns at the centimeter scale and to compare fine-scale vertical trends in relative resistivity.

Grainstone facies typically display a uniform low-resistivity texture, displayed in the gray-scale imagery as a homogeneous dark gray interval.

Packstone to wackestone facies generally had a more uneven centimeter-scale resistivity, presumably resulting from differential abundances of carbonate mud and the related extent of partial cementation during diagenesis. Therefore, the FMS imagery displays a more mottled appearance with irregular diffuse higher resistivity patches ("light-gray mottles"). In some wackestone-packstones, especially in recovered cores in lagoonal gastropod-pellet facies, significant leaching of the larger bioclasts has created a moldic porosity within a porous wackestone matrix. The corresponding FMS imagery displays a "medium-gray," moderate-resistivity background with abundant dark (leached) spots and some diffuse patches of preferential cementation.

In facies having algal-enhanced concentrations of carbonate mud, such as algal-flat intervals or red-algal encrustations and coral-algal banks, horizontal lenses of high-resistivity material are distributed within a low-resistivity matrix.

Rudstone (mainly beds of storm-washed rubble) or boundstone beds (not observed in the FMS logs within this lagoonal setting) display a "blocky" texture of 10-cm-scale, rounded and sharp-bordered patches of contrasting resistivity. An interpretation of "storm bed" is assigned to distinct higher resistivity or "rubble" beds with sharp bases occurring within an otherwise homogeneous wackestonepackstone facies.

Our independent calibration of carbonate textures to FMS imagery appearance is similar to the relationships observed in the logs in the carbonate platforms of the guyots drilled on the preceding Leg 143 (Cooper et al., 1995); however, there are some minor nomenclature and implied depositional environment differences. These differences are mainly the result of the calibration of the FMS imagery to shipboard descriptions of the same sediments. For example, the "mudstone with moldic porosity" facies of Cooper et al. (1995) displays the same FMS texture as our "bioclastic wackestone-packstone" classification. The sediments recovered in this facies consist of abundant bioclastic molds in wackestone-packstone that had undergone extensive diagenetic "chalkification"; therefore, it was not initially a mudstone, and we have tried to maintain the shipboard sedimentological nomenclature of the facies before extensive diagensis.

\section{Recovered Sediments}

Recovery was typically less than $5 \%$ of each cored interval. Core recovery was highest when the cored facies consisted of uniformly moderate-cemented carbonates. Neither well-cemented beds, which apparently shattered upon drilling, nor poorly cemented facies, which disintegrated under the drill, had significant recovery. Interbedded well- and poor-cemented beds, such as occur in the shallow-water upward-shoaling facies successions or parasequences, had recovery biased toward the uppermost well-cemented bed. Similar recovery biases were noted in the Leg 143 drilling of guyots (Cooper et al., 1995). Unfortunately, an implication is that those intervals which contain a significant amount of vertical variation (hence of the most value to interpretations of changing depositional environments and possible sea-level changes) also have the lowest recovery of sediments to enable direct sedimentological interpretation of facies trends.

\section{Model of Depositional Facies}

The vertical succession of carbonate facies reflect changing depositional environments of wave energy (winnowing or deposition of carbonate mud), of ecological zones (algal mat, coral, gastropod, etc.), and of relative water depth (emergent horizons, downslope debris, etc.). Interpretation of relative shifts of facies (e.g., lagoonward versus seaward; upward-shallowing versus deepening) requires a basic conceptual model of the original distribution and depositional environments of the various carbonate facies (Fig. 2).

Lagoonal facies present a particular problem because of the difficulty of identifying episodes of prograding coral-algal production ("carbonate factory") creating parasequences or of transgressive backstepping of seaward facies. Instead, a relative depth-facies interpretation can be made according to the relative proportion of lime-mud, the relative importance of storm events disrupting sedimentation or washing in beds of coarser debris, and the biological assemblages. However, such "deepening" and "shallowing" trends can be obscured by changes in the degree of restriction of the lagoon floor from the open sea. A "quiet" lagoon facies might imply a greater degree of restriction rather than a deeper water setting. Also, an increased abundance of storm-bed layers might reflect a greater proximity of grainstone-rudstone shoals rather than an upward-shallowing of the lagoon floor.

For placing the cored and logged facies of this Paleocene-Eocene atoll into a context of adjacent depositional environment belts, we used a simple model that combines relative mud content and biological assemblages. We used an idealized succession from the deep "lagoon" facies deposited in relatively quiet waters and/or distant from reef-shoal barriers through the shallow "lagoon" facies or intertidal depths in the lee of barrier shoals to the "island" facies formed by storm accumulations from the seaward active carbonate-sediment factory: (1) mudstone to wackestone with small benthic foraminifers; (2) wackestone-packstone with gastropods and miliolid foraminifers; (3) packstone, which may contain layers of storm-redeposited or -winnowed in situ grainstone or rudstone; (4) algal-rich facies, which may contain algal-concretions (oncolites or rhodoliths) in packstonegrainstone, and generally has an associated concentration of uranium producing an elevated natural gamma-ray intensity; (5) winnowed grainstone of various bioclasts and foraminifers, or partially cemented packstone with fenestral features of possible intertidal or algal mat origin; (6) emergent grainstone-rudstone shoal or island with coarse storm-redeposited debris from the seaward "carbonate factory"; and (7) coral-algal reef flat.

This conceptual model of relative lagoonal depth is partially based on comparisons with Tertiary atoll lagoon settings. However, the "lagoonal" facies may also be developed in interiors of platforms like the Bahama Banks which have a partial barrier (reefs and shoals) only on the windward side. It is not certain that these Cretaceous guyots had a true atoll morphology during much of their development. There- 


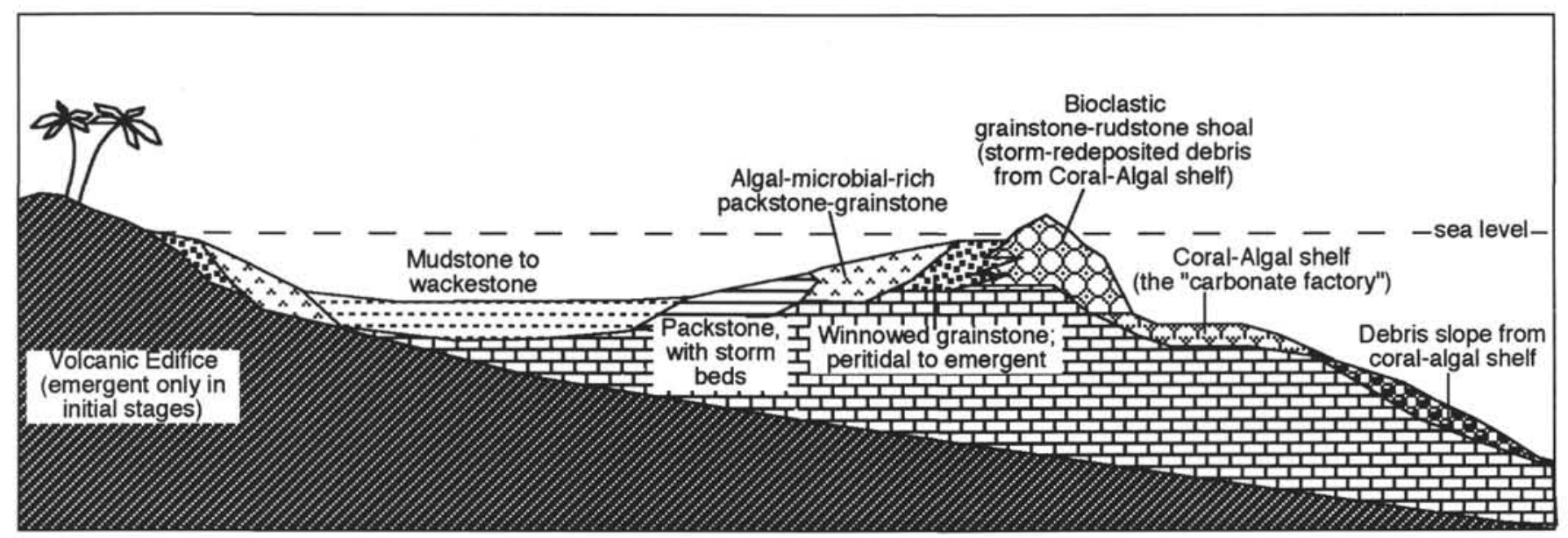

Figure 2. Idealized model of carbonate facies across a guyot platform. A quiet-water lagoon forms in the lee of shoal deposits of wave-redeposited bioclastic debris. Algal-cyanobacteria features and storm reworking occur preferentially in the shallower depths of the lagoon. A typical transgressive facies succession during initial submergence of the former volcanic island is wave-winnowed grainstone, algal-or oncoid-rich packstone, and lime-mud-rich lagoonal sediments.

fore, "lagoon" is used here in a broad sense as a partially protected interior of the carbonate bank.

Algal-cyanobacterial mats and oncoids have a wide depth range. In Hole 878 , these microbial features (often generalized as "algal" in the following descriptions, even though cyanobacteria play the major role) commonly are associated with a packstone-grainstones facies, which we generally interpret to represent a shallower depth than a lime-mudrich facies. However, a transition from a skeletal wackestone with fenestrae features to an oncoid packstone would imply a deepening trend.

Carbonate platform facies of all geological ages typically have upward-shallowing cycles or parasequences superimposed upon larger scale trends. A "parasequence" is defined as "a relatively conformable succession of genetically related beds or bed sets bounded by marine flooding surfaces or their correlative surfaces ... separating younger strata from older strata across which there is evidence of an abrupt increase in water depth" (Van Wagoner et al,, 1990). These parasequences or upward-shallowing facies successions are typically of meter-scale thicknesses and have recurrence periodicity similar to Milankovitch orbital-climate cycles, although the exact causes of the cyclicity are debated (e.g., reviews in Wilson, 1975; Tucker and Wright, 1990; Jones and Desrochers, 1992; Pratt et al., 1992). A few intervals within Hole $871 \mathrm{C}$ were dominated by repetitious, $\sim$-m-thick cycles of upward-increasing resistivity sharply terminated to the lower resistivity base of the following cycle. These cycles were dominant when the depositional environment was "shallow lagoon to intertidal," and typically incorporated the upward-shallowing suite of uncemented wackestone-packstone to algal-rich carbonate to relatively wellcemented packstone-grainstone. The associated FMS imagery and natural gamma-ray characteristics indicated that the uppermost highresistivity zone of each cycle appeared to be a cemented grainstone, which we interpret as a downward cementation episode associated with an emergence or condensation horizon on a shallow shoal of grainstone debris. In these cases, the upward-increasing resistivity is not caused by an increased carbonate mud component but, rather to an anomalous cementation level. However, similar upward-increasing resistivity cycles were interpreted as "upward-fining sequences" in the borehole logs into lagoonal facies of Cretaceous guyots drilled on Leg 143 (Cooper et al., 1995).

\section{INTERPRETATION OF DEPOSITIONAL HISTORY}

The following depositional history of the carbonate facies integrates the independent observations from the cored sediments (typically only $20-50 \mathrm{~cm}$ of recovery from each $10-\mathrm{m}$ cored interval), the quantitative resistivity measurements, the variation in natural gammaray intensities and associated uranium/thorium/potassium abundances, and the detailed FMS records of "textures" and vertical successions. Division of the lithologic succession into subunits was based initially upon the facies and nomenclature of shipboard-defined lithologic units. At Site 871, the entire carbonate platform succession was denoted as lithologic Unit II with six lettered subunits. The continuous downhole logging records enabled improved resolution of the boundaries or transitions between these lithologic subunits (Table 1) and allowed additional subdivisions to be defined as coherent log-facies packets or as major parasequences (Fig. 1). Summaries of the recovered lithologies of these subunits and details of the signatures and interpretation of possible depositional facies for the associated downhole logging subdivisions are compiled in the Appendix. Two important assumptions are required for this interpretation of the depositional history of Site 871. First, it is assumed that the logging characteristics and associated core recovery are representative of an unambiguous facies and associated depositional environment. The Shipboard Scientific Party (1993) compiled a preliminary depositional history of Limalok Guyot based mainly on the recovered facies. The broad outlines of their interpretation are similar to this study, however, the details differ significantly in many intervals because we have relied heavily on the high-resolution FMS imagery to identify facies characteristics where core recovery is meager or nonexistent.

Second, it is assumed that the facies within Hole $871 \mathrm{C}$ reflect large-scale trends within the central portion of Limalok Guyot, rather than local shifts and isolated patterns of environments. The assumption of local versus general facies trends is particularly important for the interpretation that upward-shallowing parasequences reflect eustatic sea-level fluctuations rather than autocyclic behavior of the carbonate system. The interpretation of carbonate upward-shallowing cycles within isolated outcrops or logging data is debated (e.g., Osleger, 1991; Drummond and Wilkinson, 1993a, 1993b; Goldhammer et al., 1993; Grötsch, 1994). However, most regional studies have concluded that the major facies trends and sets of parasequences within a single outcrop are indicative of larger scale patterns of facies shifts and carbonate sequence system tracts, rather than an artifact of random or autocyclic facies changes (e.g., Goldhammer et al., 1990; Van Wagoner et al., 1990; Osleger and Read, 1993; Gräfe and Wiedmann, 1993). Therefore, the major deepening or shallowing trends interpreted within Hole $871 \mathrm{C}$ are considered to be indicative of broader facies trends within the central portion of the Limalok Guyot carbonate platform. and it is assumed that these trends provide a monitor of relative sea-level changes with respect to the platform. 
Table 1. Lithologic subunit boundaries of the carbonate platform succession in Hole 871C assigned from FMS imagery and other borehole logs compared to shipboard assignments from core recovery.

\begin{tabular}{|c|c|c|c|c|c|}
\hline $\begin{array}{l}\text { Unit or } \\
\text { subunit }\end{array}$ & $\begin{array}{l}\text { Lithology } \\
\text { (brief summary) }\end{array}$ & $\begin{array}{l}\text { Base in } \\
\text { borehole } \\
\text { (mbsf) }\end{array}$ & $\begin{array}{l}\text { Thickness } \\
\text { (m) }\end{array}$ & $\begin{array}{c}\text { Shipboard } \\
\text { assignment } \\
\text { (core, section, } \\
\text { interval [in } \mathrm{cm}] \text { ) }\end{array}$ & $\begin{array}{c}\text { Shipboard } \\
\text { estimate } \\
\text { of base } \\
\text { (mbsf) }\end{array}$ \\
\hline I & Pelagic foraminifer ooze & 139.5 & 139.5 & $6 \mathrm{R}-1,0$ & 133.7 \\
\hline IIA & Foraminifer packstone-wackestone & 161.72 & 2.2 & $6 \mathrm{R}-1.0$ & 153.2 \\
\hline IIB & Foraminifer wackestone to skeletal grainstone & 182.92 & 1.2 & $7 \mathrm{R}-1,0$ & 181.9 \\
\hline IIC & Composite of lithologies, dominated by foraminifer packstone-wackestone & 320.3 & 137.4 & $21 \mathrm{R}-1,16$ & 316.7 \\
\hline IID & Foraminifer packstone and algal-coral grainstone & 387.7 & 67.4 & $27 \mathrm{R}-1,0$ & 374.3 \\
\hline IIE & Algal- and rhodolith-rich grainstone-packstone; cyclic & 421.9 & 34.2 & $31 \mathrm{R}-1,21$ & 413.0 \\
\hline IIF & Gray foraminifer-mollusk packstone-grainstone with pyrite and organic carbon & 425.7 & 3.8 & $32 \mathrm{R}-1,40$ & 422.9 \\
\hline III & Claystone formed from weathered volcanic breccia & 451.6 & 25.9 & $35 \mathrm{R}-1,5$ & 451.6 \\
\hline IV & Basalt flows and volcanic breccia & $>500.0$ & $>48.4$ & $41 \mathrm{~B}-1,42$ & \\
\hline
\end{tabular}

\section{Weathering and Submergence of the Volcanic Edifice (451.6-425.7 mbsf; Lithologic Unit III; late Paleocene)}

Massive alkaline basalt flows and interbedded volcanic breccia are overlain by weathered volcanic breccia and associated overlying variegated clayey soil. Soil formation and deeper partial weathering under tropical conditions penetrated approximately $26 \mathrm{~m}$ (to 451.6 mbsf) into the volcanic edifice, although the lower $15 \mathrm{~m}$ may be thickened by slump deposits.

The uppermost meter of gray clay contains small gastropods and patches of sand-sized fragments of marine organisms (mollusks and foraminifers). However, the onset of carbonate platform deposition is a sharp contact at $425.7 \mathrm{mbsf}$. The uppermost gray clay with redeposited bioclasts is interpreted as a marginal-marine marsh to nearshore mud with partial bioturbation mixing of sand-sized bioclastic debris carried landward by waves or storms. This marginal-marine mud also preserved some rare pelagic nannofossils.

\section{Storm-redeposited Bioclastic Sands, Shallow-water Algal-rich Parasequences, and Exposure Surfaces (425.7-387.7 mbsf; Lithologic Subunits IIF and IIE; late Paleocene)}

The basal $4 \mathrm{~m}$ of the carbonate platform (Subunit IIF) consist of seven beds of gray, poorly sorted grainstone to packstone, comprised primarily of foraminifer and mollusk fragments, with thin $(\mathrm{ca} .10 \mathrm{~cm}$ thick) interbeds of clay-rich sediment. These beds probably represent storm-redeposited material, derived from an inner shelf environment or from an offshore "lagoon," that have been washed onto a beach or intertidal setting. An upward increase in resistivity and calcium abundance corresponds to a progressive decrease in average clay content and an increase in degree of cementation. Therefore, a series of storm-redeposited shoal accumulations are interbedded with clayrich sediment and organic material washed from the adjacent volcanic island. Cementation of these beds may have been enhanced under the low-oxygen conditions, but yellowing limonite weathering and the sharp surface on the uppermost bed ( $421.9 \mathrm{mbsf})$ indicates at least one period of emergence. The emergent surface may also represent a relative drop of sea level, because upward-shallowing algal-rich parasequences also characterize the overlying Subunit IIE. Therefore, this initial carbonate-sand-rich cycle of submergence and emergence may represent a single upward-shallowing parasequence.

The next $34 \mathrm{~m}$ are a series of six main cycles or upward-shallowing parasequences (Subunits IIE-1 through IIE-6). The uppermost main parasequence appears to be a composite of four thin parasequences (Subunits IIE-6a to IIE-6d). The top of each parasequence is a sharp surface, overlain by the low-resistivity base of the next parasequence (Fig. 3). The dominant lithology is algal-rhodolith-rich grainstone-packstone with abundant benthic foraminifers, coral and mollusk fragments. Lenticular, 10 - to 20 - $\mathrm{cm}$-thick bodies of relatively higher resistivity in the FMS imagery are interpreted to be produced by algal mats. The enrichment in uranium in these cycles is probably caused by redox-concentration processes associated with the algal microenvironments. The maximum uranium content just below the upper peak in cementation of each parasequence may be a combination of enrichment in algal components and of a redox concentration associated with an uppermost emergence. The lower set of algal-rich parasequences (Subunits IIE-1 through IIE-3) average $5 \mathrm{~m}$ in thickness and commonly display meter-thick fluctuations in resistivity and uranium contents superimposed on the main trend of upward-increasing resistivity. The meter-scale fluctuations are probably caused by variations in lime-mud content, in abundance of algal mats and rhodoliths, and in degree of cementation.

The fourth parasequence (Subunit IIE-4, 3 m thickness) terminates in a well-cemented surface, interpreted as a brief emergent episode. The overlying set of parasequences are relatively thin, averaging only about $2.5 \mathrm{~m}$ in thickness, and are dominated by algal-mat facies (Fig. 3).

Subunit IIE is interpreted as a late highstand systems tract followed by an period when falling sea levels were limiting accommodation space for sediment accumulation. A "sequence boundary," corresponding to the most rapid rate of eustatic sea-level fall, is tentatively assigned to $400.1 \mathrm{mbsf}$. At this level, a surface of emergence marks the change between a lower interval of well-developed, 5-m-thick parasequences (typical of highstand facies) to an upper interval dominated by algal flats and thin condensed parasequences. Subunit IIE is terminated by a rapid deepening trend.

The submergence of the weathered volcanic edifice in Hole 871C appears to be associated with the deep-water phase of an upwardshallowing parasequence. Therefore, the upper portion of Subunit IIE (parasequences IIE-4 through IIE-6) may equivalent to a lowstand systems tract developed on shelves with slower subsidence rates.

\section{Major Cycle 1: Deepening Episode, Protected Lagoon, and Shallowing to Algal-rich Parasequences and Exposure Surfaces (387.7-320.3 mbsf; Lithologic Subunit IID; late Paleocene)}

Subunit IID is a complete cycle of a basal transgressive surface (387.7 mbsf; Fig. 3) and progressive deepening (Subunits IID-1 through IID-3, $34 \mathrm{~m}$ total thickness), followed by a rapid shallowing ( $347.2 \mathrm{mbsf}$ ) to a series of six major algal-rich parasequences (Subunits IID-4 to IID-7, $33 \mathrm{~m}$ total thickness), which are terminated by another transgressive surface (ending at $320.3 \mathrm{mbsf}$ ).

The first deepening phase (Subunit IID-1, $12 \mathrm{~m}$ thickness) is dominated by foraminifer packstone and algal-rich intervals. This phase consists of two upward-increasing resistivity and uranium cycles, which may be upward-shallowing parasequences superimposed on a general deepening trend. The cycles are thicker $(6 \mathrm{~m})$ than the underlying "highstand" parasequences of Subunit IIE (4-5 m); these expanded thicknesses are consistent with a transgressive trend. Further deepening produces a moderate depth-protected lagoon with a lime-mud-rich facies of gastropod-rich foraminifer-skeletal wackestone-packstone (Subunit IID-2; $17 \mathrm{~m}$ ). 
The late stage of this lagoon (Subunit IID-3, $5 \mathrm{~m}$ thickness) displays a progressive upward increase in resistivity. The associated facies of foraminifer-pellet grainstone with scattered lenses of red-algal encrustations indicates a shallowing and increase in winnowing.

The overlying shallow-water portion of Cycle 1 consists of two algal-rich intervals with an intervening brief return to deeper lagoonal conditions. The lower algal-rich interval (Subunits IID-4 and IID$5,13.6 \mathrm{~m}$ total thickness) appears to consist of a series of thin, upward-shallowing parasequences. There may be approximately six thin cycles grouped in two major sets. Uranium concentrations display several major peaks. The sharp top of a major well-cemented bed at 347.2 mbsf is probably an exposure surface. Subunits IID-4 and IID-5 are interpreted to be an algal-mat-rich environment, with possible shallowing to peritidal conditions.

A minor deepening event (340.2 mbsf; Fig. 4) produces a 7-mthick facies (Subunit IID-6) with low resistivity and low uranium content. FMS imagery and associated core recovery indicate a foraminifer-skeletal packstone with subordinate algal accumulations. This interval is interpreted to represent a moderate-depth lagoon environment. The uppermost portion of this unit, characterized by upward-increasing resistivity and uranium content, is transitional to the second algal-rich interval.

The upper algal-cyanobacterial-rich interval (Subunit IID-7, $13 \mathrm{~m}$ thickness) displays the greatest uranium concentrations within the carbonate platform. This interval contains four main parasequences with upward-increasing resistivity. Core recovery indicates a mixed assemblage of algal grainstone, coral-gastropod rudstone-packstone, and foraminifer grainstone. The lower two parasequences (Subunits IID-7a and IID-7b, averaging $3 \mathrm{~m}$ in thickness) have sharp tops on well-cemented capping beds, which are interpreted to be possible surfaces of exposure. The uppermost parasequence (Subunit IID-7d, $5 \mathrm{~m}$ thickness) may be superimposed on the initiation of a deepening trend (Fig. 5).

A possible interpretation is that Cycle 1 consists of a major transgressive system tract (Subunits IID-1 and IID-2) and a highstand systems tract (Subunit IID-3 through IID-6). Subunit IID-7 may be equivalent to a lowstand systems tract developed on margins with slower subsidence rates, but an actual lowstand deposit was not observed on this rapidly subsiding guyot. Maximum flooding occurs in Subunit IID-2, and a sequence boundary is tentatively placed at the rapid transition ( $327.3 \mathrm{mbsf}$ ) to upward-shallowing algal-cyanobacterial-rich cycles and emergent episodes.

At least one secondary set of systems tracts with associated transgressive and rapid-shoaling ( sequence boundary ) surfaces is within the main succession of the Cycle 1 facies. The possible emergent surface at $347.2 \mathrm{mbsf}$ within this secondary cycle may represent a minor sequence boundary. Numerous parasequences are superimposed on these main trends. The entire suite and overlying deepening phase of Cycle 2 were assigned to composite Subunit IIC by the Shipboard Scientific Party (1993), because core recovery was inadequate to identify the various facies trends.

\section{Cycle 2: Major Deepening Episode, Storm-influenced to Protected Lagoon, and Brief Shallowing into Algal-rich Facies (320.3-209.8 mbsf; Logging Facies Subunits IIC-1 to IIC-6; early to middle Eocene)}

The thick lithologic Subunit IIC also encompasses a complex suite of facies. The lower to middle portion contains a major deepening-shallowing succession (Cycle 2), in which the deep-water phase also contains a secondary interval of relative shallowing, producing a storm-winnowed debris interval (Subunit IIC-4). The upper part of Subunit IIC is the deepening phase of the next major cycle (Cycle 3 ).

The lagoonal facies of Cycle 2 (Subunits IIC-2, IIC-3, and IIC-5) consist of foraminifer-gastropod wackestone-packstone with variable frequencies of storm beds of packstone-grainstone to rudstone (Fig. 5). The initial transgressive deepening phase (Subunit IIC-1) and concluding shallow-water to peritidal phase (Subunit IIC-6) are algal-coral-rich parasequences and/or intervals of storm-winnowed debris.

The deepening phase took place in two main stages. Above the initial surface of deepening, marking the sharp top of Subunit IID (Fig. 5), is an interval of fluctuating uranium concentrations and resistivity peaks (Subunit IC-1, $18 \mathrm{~m}$ thickness). These beds may be grouped into at least two major sets of upward-shallowing cycles or parasequences. The dominant successions appear to be algal- or cyanobacterial-rich grainstone-packstone facies shallowing upward into an algal-cyanobacterial mat or algal-flat facies. The unit may include a partial return to the shallow-water algal-rich facies of the underlying Subunit IID-7.

The second deepening phase (302.4 mbsf) established a storm-influenced lagoon (Subunit IIC-2, $26 \mathrm{~m}$ thickness). Foraminifer-gastropod packstone-wackestone dominates, and algal-components are absent. FMS imagery and resistivity logs display sharp-bounded moderate-resistivity beds of coarser bioclasts and/or rudstone interspersed within the low-resistivity packstone (Fig. 6). These distinct beds are interpreted to be storm-reworked or -winnowed accumulations of coarser bioclasts and/or rudstone. This lime-mud-rich interval represents the formation of an effective atoll structure, with a partially protected lagoon, in contrast to the algal-flat facies that dominate the underlying carbonate platform subunits.

Further deepening and/or restriction of the lagoon (276.4 mbsf) decreases the abundance of storm beds, and the next $53 \mathrm{~m}$ is dominated by foraminifer and peloid wackestone-packstone (Subunits IIC-3 through IIC-5). Extensive micritization has produced a chalky appearance.

An interval with several concentrations of coarse bioclasts and/or rudstone within the middle of this facies (Subunit IIC-4, 13 m thickness; Fig. 7) indicates a less protected lagoon environment. This interval of storm reworking or redeposition may indicate a relative shallowing of the lagoon depths, and the possibility of a minor sequence boundary at the base. The interpreted minor sequence boundary at the base ( $248.0 \mathrm{mbsf}$ ) may correspond to the Ilerdian/Cuisian boundary according to microfaunal indications. A peak in uranium content also suggests a brief episode of algal-cyanobacterial enrichment within these deposits. Protected lagoon conditions return in Subunit IIC-5.

A second series of storm-redeposited beds interrupt the quiet-lagoon conditions, which is followed by a shallowing into a thin interval of algal-cyanobacterial-rich facies (Subunit IIC-6, $14 \mathrm{~m}$ thickness). The uppermost sharp-topped high-resistivity bed coincides with a peak in uranium and is interpreted to be a thin interval of algal-cyanobacterial-rich facies, similar to those of the parasequences of Subunit IID. However, this bed is sharply overlain by another lagoonal deposit (Subunit IIC-7), indicating the transgressive onset of Cycle 3. In some respects, this storm-bed and postulated algal-cyanobacterial-rich interlude could be considered as merely a minor regressive episode within a major combined Cycle 2 and 3 , because sustained shallow-water conditions are not established until the top of Cycle 3.

In general, depositional environments in Subunit IIC are significantly more lagoonal in character than the underlying algal-rich Subunits IIE and IID. The deepening event at the base of this subunit (320.3 mbsf; Fig. 5) may coincide with the Paleocene/Eocene boundary. A sea-level rise at the end of the Paleocene may have triggered a rapid upward growth of the outer coral-algal reef complex, thereby producing a morphology of a true atoll with inner protected lagoon. Before this sea-level rise, the interior of the Limalok platform may have resembled a shallow bank that alternated between a currentswept, grainstone-packstone floor or a peritidal flat with extensive algal mats and rhodoliths. 


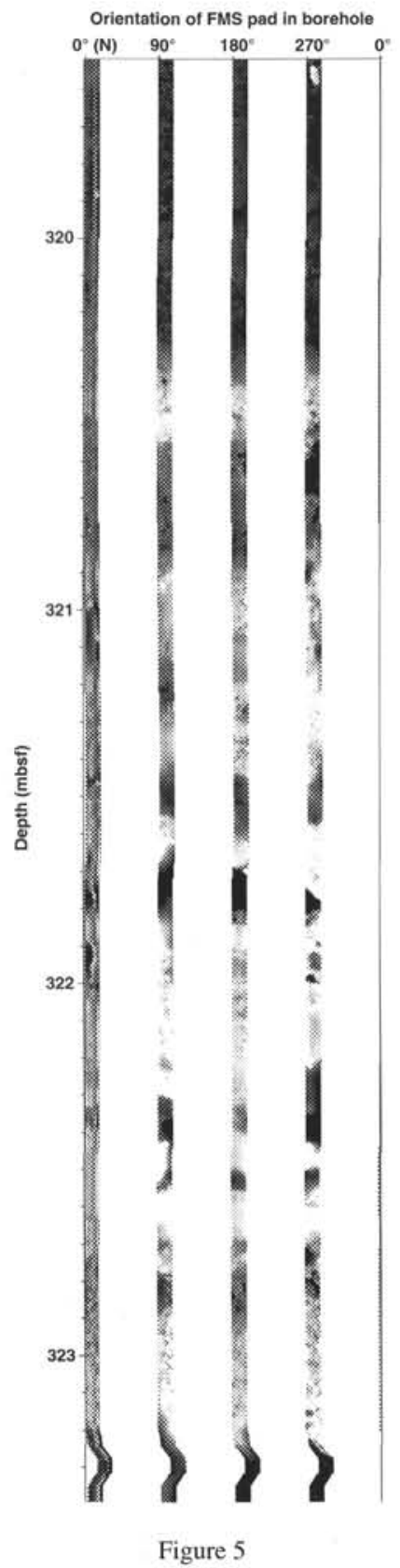

Figure 3. FMS static-processed image from the uppermost portion of logging-facies Subunit IIE-6 (upward-shallowing algal-rich facies successions) and the lowermost portion of Subunit IID-1 (lagoon facies of foraminiferpellet packstone). This interval (386-390 mbsf, corresponding approximately to Core 144-87IC-28R) is of Paleocene age. Subunit IIE-6 is characterized by cycles of upward-increasing resistivity, with a sharp transition to the overlying low-resistivity base of the next cycle; a complete cycle is displayed from 389.8 to $387.6 \mathrm{mbsf}$ (fourth cycle in Subunit IIE-6). The lenticular to tabular, higher resistivity bands in these cycles are probably caused by algal-enhanced cementation. Subunit IID-I has a homogeneous granular texture (dark gray to black in this FMS image), and its sharp lower contact at 387.6 mbsf to Subunit IIE represents a transgressive deepening episode. In this and all following FMS images, the high-resistivity beds are shown in white and low-resistivity beds are in black; the gray-scale contrast for relative resistivity has been maximized over the displayed image interval using NIH Image software; the orientation of the four FMS traces are clockwise around the borehole, with magnetic north on the left edge fixed by a borehole magnetometer in the FMS tool; the borehole circumference is approximately $1 \mathrm{~m}$.

Figure 4. FMS static-processed image from the upper portion of loggingfacies Subunit IID-5 (algal-coral flat facies with an upward-shallowing cycle), overlain at 340.2 mbsf by logging-facies Subunit IID-6 (foraminifer packstone). This interval (339-343 mbsf, corresponding approximately to Core 144-871C-23R) is of Paleocene age. Subunit IID-5 is characterized by thin, discontinuous, high-resistivity bedsinterbedded with relatively lowresistivity layers with a grainstone-packstone texture. The thin, Ienticular to tabular, higher resistivity bands in these cycles, such as the bed at 340.9 mbsf, are probably caused by algal-enhanced cementation. Subunit IID- 6 has a low-resistivity grainstone-packstone texture with scattered higher resistivity 5- to 10-cm-thick lenses and ca. 1-cm higher resistivity balls, which probably represent inhomogeneous cementation. The transition between the underlying algal-rich facies into a typical lagoon facies indicates a deepening event. Format of FMS image is explained in Figure 3.

Figure 5. FMS static-processed image of the facies transition near the Eocene/Paleocene boundary (323-320 mbsf, corresponding approximately to Core 144-87IC-2IR). Logging facies Subunit IID-7 is an algal-rich facies with upward-shallowing cycles or parasequences of low to medium resistivity changing upward to high resistivity. Dynamic FMS imagery indicates a combination of laminated algal mats and grainstone to rudstone beds. It is sharply overlain at $320.3 \mathrm{mbsf}$ by Subunit IIC-1 of lagoonal foraminifer packstone of low resistivity (black in FMS image). The basal portion of Subunit IIC-1 is homogeneous with a rhodolith -bearing grainstone appearance in the dynamic FMS imagery. This transition between the algal-rich facies and a shallow lagoon facies indicates a major deepening event. Format of FMS image is explained in Fig. 3. 


\section{Cycle 3: Deepening Episode, Protected Lagoon, and Shallowing to Algal-mat Facies (209.8-152.9 mbsf; Logging Facies Subunits IIC-7 and IIC-8, Lithologic Subunit IIB, and Logging Facies Subunit IA-1; early to middle Eocene)}

Protected lagoon conditions and lime-mud-rich sediments dominate the lower $27 \mathrm{~m}$ of Cycle 3 , with only a short interval containing some loosely cemented beds of storm-winnowed debris (Subunits IIC-7 and IIC-8). The sedimentation is dominated by gastropod- and bivalve-bearing foraminifer wackestone-packstone. A relative shallowing and/or increasing exposure to storm waves produces an increasing abundance of winnowed grainstone and sharp-bounded storm beds of coarse debris and rudstone (Subunit IIB-1, 13 m thickness). The top of this storm-bed-rich interval displays a peak in uranium. Algal-cyanobacterial-rich parasequences and peritidal sediments dominate the next $17 \mathrm{~m}$ (Subunits IIB-2 and IIA-1; Fig. 8),

The lower interval of the algal-cyanobacterial-rich (high uranium content) facies (Subunit IIB-2, $8 \mathrm{~m}$ thickness) has four to five cycles of upward-increasing resistivity with sharp upper surfaces (Fig. 8). At least one of these parasequences included a brief period of emergence. Core recovery within the upper interval of algal-cyanobacterial-rich facies (Subunit IIA-1, $9 \mathrm{~m}$ thickness) included foraminiferintraclast grainstone with keystone vugs, suggesting occasional peritidal conditions.

Cycle 3 can be subdivided into a deepening phase or transgressive systems tract (Subunit IIC-7), a gradual shallowing-upward phase or highstand systems tract (Subunits IIC-8 through IIB-2), a brief emergence near 169.6 mbsf (sequence boundary?), and establishment of a subtidal to peritidal facies rich in algal-cyanobacterial features or microbial mats (Subunit IIA-1). Subunit IIA-1 is terminated by a deepening event ( $152.9 \mathrm{mbsf})$ and return to lagoon conditions; therefore, its position between a possible sequence boundary and an overlying transgressive transition would imply that it may be the equivalent of a lowstand system tract on shelves with slower subsi-dence rates.

\section{Progressive Drowning of the Carbonate Platform (152.9-139.5 mbsf; Logging Facies Subunits IIA-2 to IIA-4; middle Eocene)}

Core recovery of a foraminifer packstone coincides with a 6-m interval of moderate-resistivity, low-uranium facies with a diffuse mottled packstone texture in the FMS imagery (Subunit IIA-2). This interval is interpreted as a quiet lagoon environment.

The overlying $6 \mathrm{~m}$ displays peaks in resistivity and uranium content, and the FMS imagery indicates 10 -cm-thick, high-resistivity lenses within a granular texture host sediment (Subunit IIA-3; Fig. 9). These characteristics are similar to Subunit IIA-1; therefore, the facies is interpreted to be an algal-rich grainstone deposited in relatively shallow depths.

The uppermost $1.3 \mathrm{~m}$ of the carbonate platform is a high-resistivity, well-cemented bed associated with a concentration of uranium (Subunit IIA-4; Fig. 9). FMS imagery and core recovery indicate that this is a foraminifer wackestone-packstone. The uranium content is interpreted to be a redox concentration process associated with the formation of the capping phosphatic and iron-manganese crust.

This succession is interpreted as a lagoonal packstone-wackestone (Subunit IIA-2) shallowing upward to an algal-cyanobacterialrich facies (Subunit IIA-3), capped by a cemented phosphate-rich bed of lagoonal packstone-wackestone (Subunit IIA-4). Therefore, the drowning of the carbonate platform at this site begins with a transgressive surface at the top of the algal-flat facies of Subunit IIA-3. The final Subunit IIA-4 represents a partially preserved, deeper water facies that accumulated during the drowning.

\section{DISCUSSION AND CONCLUSIONS \\ Paleocene Eocene Platform History and Sequence Stratigraphy Correlation}

A major goal of Leg 144 was to use the stable subsidence rates of carbonate platforms as dip sticks to measure the timing and magnitude of major eustatic sea-level fluctuations (e.g., Lincoln and Schlanger, 1991). Limalok Guyot provides a record of major late $\mathrm{Pa}-$ leocene to middle Eocene sea-level changes, and the major events appear to be identical to published eustatic curve compilations (e.g., Haq et al., 1988). However, the exact timing of these sea-level events was precluded by the absence of a detailed biostratigraphic framework, and the magnitude of rises and falls was distorted by the rapid subsidence rate of the seamount.

The Paleocene-Eocene platform succession at Site 871 displays six main deepening episodes, culminating in a two-stage final drowning (Table 2). Sedimentation between each pair of episodes generally consists of a deep-water phase followed by an upward shallowing to an algal-rich parasequence suite. Some of the shallow-water parasequences include surfaces of emergence. The thicker deposits also encompass minor deepening and shallowing cycles.

The initial submergence of the volcanic edifice was followed by a sustained shallow-water to peritidal algal-rich depositional environment (Subunits IIF and IIE). After a major second deepening episode, the Paleocene platform underwent a progressive upward shoaling punctuated by a series of upward-shallowing facies successions and possible emergent episodes (Subunit IID).

A third major deepening occurs near the Paleocene/Eocene boundary into a thick interval of lagoon wackestone-packstone with episodes of storm reworking (Subunits IIC-1 to IIC-5). This early Eocene lagoon has a general long-term shoaling, culminating in a peritidal algal-mat facies (Subunit IIC-6). A fourth, but less major deepening event produces a return to lagoonal conditions (Subunits IIC-7 to IIB-1), followed by another shoaling to a shallow-water to peritidal facies and possible emergent episodes (Subunits IIB-2 and IIA-1).

A middle Eocene transgressive pulse submerges the shallow-water environment, but is immediately followed by a upward-shoaling cycle and a brief partial reestablishment of the algal-rich facies (Subunits IIA-2 and IIA-3). The shallow-water platform is permanently drowned by another major transgressive pulse.

If Limalok Guyot had a steady rate of subsidence during the late Paleocene and Eocene, then these six main deepening events are a record of significant transgressive rises of eustatic sea level. The onset of these rapid transgressive rises are the most distinctive feature in these carbonate platform successions.

In contrast, a depositional sequence on clastic margins is defined as the package of sediments deposited between successive major falls of eustatic sea level which produce unconformities across significant portions of the continental shelf and epicontinental basins. On a rapidly subsiding seamount, these eustatic sea-level falls and associated sequence boundaries will partially cancel the effects of subsidence and cause a slowing or elimination of accommodation space for accumulation of carbonate sediments. Therefore, a sequence boundary is recorded by the guyot carbonate platform as an unusually rapid transition to a sustained interval of shallow-water facies punctuated by short-period condensed parasequences or as periods of emergence. To produce a sustained unconformity, such as those that characterize sequence boundaries on ramping continental shelves, the rate of eustatic sea-level fall must exceed the typical seamount subsidence rates of 30-50 m/m.y. Possible equivalents of these sequence boundaries within the carbonate platform succession are listed in Table 2. However, in many cases, the recognition and placement of such sequence boundaries (rapid shallowing events) are ambiguous, because upward-shallowing and progradation episodes may also occur during stillstands and highstand systems tracts. 
Figure 6. FMS static-processed image of a lower Eocene lagoonal facies of foraminifer-gastropod packstone-wackestone with several storm-winnowed accumulations of coarser bioclasts or rudstone (290-293 mbsf, corresponding approximately to upper Core 144-871C-18R). Subunit IIC-2 is characterized by a medium-resistivity facies with $30-$ to 50 -cm-thick, higher resistivity horizons spaced approximately every $23 \mathrm{~m}$. Dynamic FMS imagery suggests that the higher resistivity beds, such as the levels at 292.0 and 289.6 mbsf, are a rudstone facies. Format of FMS image is explained in Figure 3 .

Figure 7. FMS static-processed image of a thick storm-winnowed debris concentration (239-242 mbsf, corresponding approximately to upper Core 144 87IC-13R) within a lower Eocene lagoonal facies of foraminifer-gastropod packstone-wackestone (Subunit IIC-4). In the dynamic FMS imagery, this bed is a concentration of high-resistivity, 2- to 5 -cm-diameter clasts within a granular-texture matrix. The sediment interbedded between these coarseclast beds, such as the low-resistivity lithology below $242 \mathrm{mbsf}$ ), is grainstone-packstone. Format of FMS image is explained in Figure 3.

Figure 8. FMS static-processed image of the upper portion of lithologic Subunit IIB (162-165 mbsf, early to middle Eocene, corresponding approximately to upper Core 144-871C-5R). This interval in logging-facies Subunit IIB-2 is winnowed foraminifer grainstone to bioclastic rudstone (gray in this FMS imagery) interbedded with high-resistivity algal-encrustation episodes (white in this image). The uppermost well-cemented, algal-encrustation episode (162 mbsf) is a possible emergence horizon and is overlain by lagoonal facies of Subunit IIA-1. Format of FMS image is explained in Figure 3. 


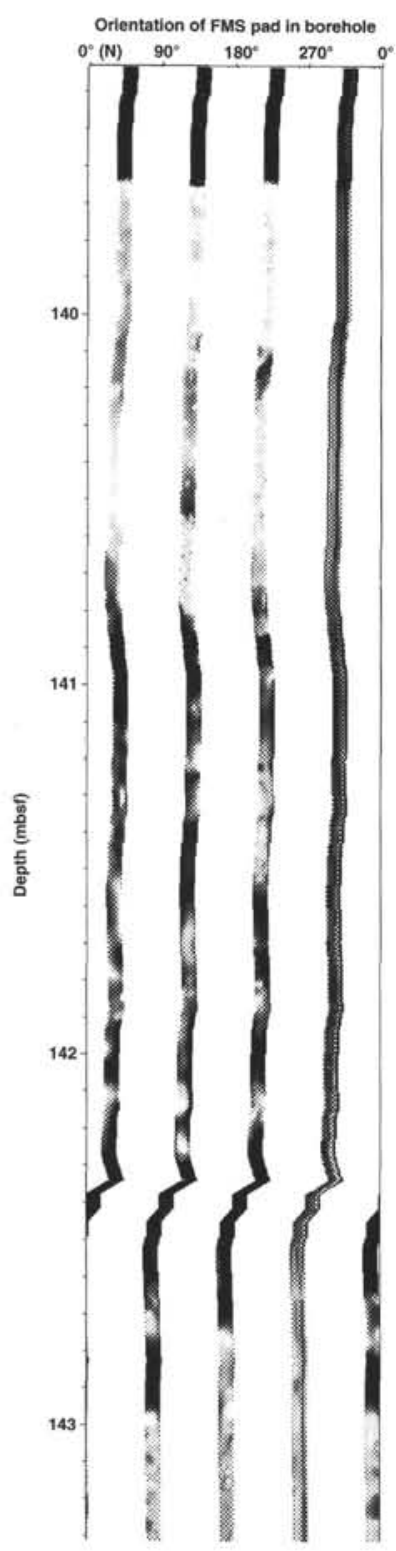

Figure 9. FMS static-processed image of the facies succession leading to the middle Eocene drowning of the platform at $139.5 \mathrm{mbsf}$, overlain by pelagic chalk. This interval (143-139 mbsf, approximately corresponding to lower Core 144-87IC-2R) spans the algal-rich Subunit IIA-3 (below $140.8 \mathrm{mbsf}$ ), the cemented phosphate-rich bed of lagoonal packstone-wackestone of Subunit IIA-4, and the pelagic chalks of basal Unit I (above $139.5 \mathrm{mbsf}$ ). Subunit IIA-3 is an algal-rich facies of encrustations or mats interbedded with packstone or low-resistivity grainstone, with possible partial dissolution in the upper $2-\mathrm{m}$ band. Subunit IIA-4 is a very high-resistivity layer with a lagoonal texture in the dynamic FMS imagery (1- to 2-cm-diameter spots of higher resistivity in a grainstone-packstone sediment). Therefore, the final preserved facies before drowning of the carbonate platform is a lagoonal-type sediment; however, this episode may represent last-stage sediment accumulation during the early stages of drowning. The actual drowning probably began at the top of the underlying algal-rich Subunit IIA-3. Indeed, this final bed may be post-drowning, redeposited sediment, that was later cemented upon further deepening below the wave base. Format of FMS image is explained in Figure 3.
The eustatic sea-level curve compiled by Haq et al. (1988) has approximately 15 numbered sequences within the late Paleocene to middle Eocene portion of the Tejas A super-sequence set (Fig. 10). However, the majority of these sequences are either relatively minor sea-level fluctuations or are too closely spaced to be adequately resolved by our log-based stratigraphic resolution at Limalok Guyot. Indeed, there are only five major sea-level rises (deepening events with greater than $25 \mathrm{~m}$ estimated magnitude) within the late Paleocene to mid middle Eocene interval. An independent derivation of a Paleocene early Eocene sea-level curve by Gräfe (1994) has the same number and ages for major excursions, but the estimated magnitudes (in meters) of these sea-level changes is approximately $50 \%$ less.

Using the Paleocene/Eocene boundary assignment at the base of Subunit IIC as the main biostratigraphic constraint, the five major eustatic sea-level rises and an additional basal highstand systems tract in the Haq et al. (1988) curve were tentatively matched to deepening events in Hole 871C (Table 2; Fig. 10). Absolute ages for the onset of each rapid rise of sea level were estimated from the time scale in the chart of Haq et al. (1988), and the corresponding age span between events were used to compute a suite of subsidence rates of the carbonate platform (Table 2). An oceanic seamount should have fairly constant rates of subsidence over a 10-m.y. interval. Therefore, if the computed set of subsidence rates from the correlation of transgressions to the Haq et al. (1988) scale are constant, then the scale is in general agreement with the Limalok stratigraphy. There are several potential problems and unknowns with such a quantitative correlation, such as the undocumented biostratigraphic calibrations and derivations of relative magnitudes for the eustatic sea-level variations in the Haq et al. (1988) compilation, the lack of adequate biostratigraphic control in Hole $871 \mathrm{C}$ to adequately justify each sequence assignments, the Ma age assignments used by the Haq et al. (1988) time scale, and the implicit assumption that absolute eustatic sea level at the beginning of each rapid deepening (sea-level rise) was approximately at the same level.

Each of the four main depositional cycles (Subunits IIF through IIA-2) yield similar subsidence rates of $25-28 \mathrm{~m} / \mathrm{m}$.y. Therefore, the duration of carbonate accumulation in Hole $871 \mathrm{C}$ is approximately 11 m.y. with a mean accumulation rate of $27 \mathrm{~m} / \mathrm{m}$.y., and is implied to span the earliest part of the late Paleocene through the earliest part of the Middle Eocene. Subsidence rates in the range of $2530 \mathrm{~m} / \mathrm{m}$.y. are expected for a carbonate platform constructed about 515 million years after initial seamount formation according to simple subsidence models of seamounts that thermally reset the underlying older oceanic crust (e.g., Detrick and Crough, 1978; Larson et al., this volume). The Marshall Islands probably had overlapping loading effects of edifices constructed during different volcanic episodes (e.g., Lincoln et al., 1993). Therefore, it is difficult to apply these simple models or more accurate complex models (e.g., Watts and Ribe, 1984; Wolfe and McNutt, 1991). Despite these complications, the subsidence rate of Limalok Guyot in the late Paleocene was probably within this same general range. An independent verification of the subsidence rate is the $\sim 3-\mathrm{m}$ thickness of the upward-shallowing parasequences recorded in the shallow-water facies in Hole 871C. These short-term upwardshallowing cycles may be related to climatic-oceanic cooling cycles induced by the 100-k.y. Milankovitch periodicity of eccentricity modulation of precession. Therefore, the 3-m-average thickness of these upward-shallowing cycles would also imply a subsidence rate of approximately $30 \mathrm{~m} / \mathrm{m}$.y.

The apparent consistent correlation of the Haq et al. (1988) curve with the independent sea-level changes, biostratigraphic constraints, and subsidence rates interpreted from the Site $871 \mathrm{C}$ logging and coring data is a surprising and unexpected agreement. Their curve is mainly derived from selected passive continental margins and may be distorted by regional tectonics and other factors, and the reliability of converting these depositional sequences into global eustatic sea-level variations is uncertain. However, we must tentatively conclude that 


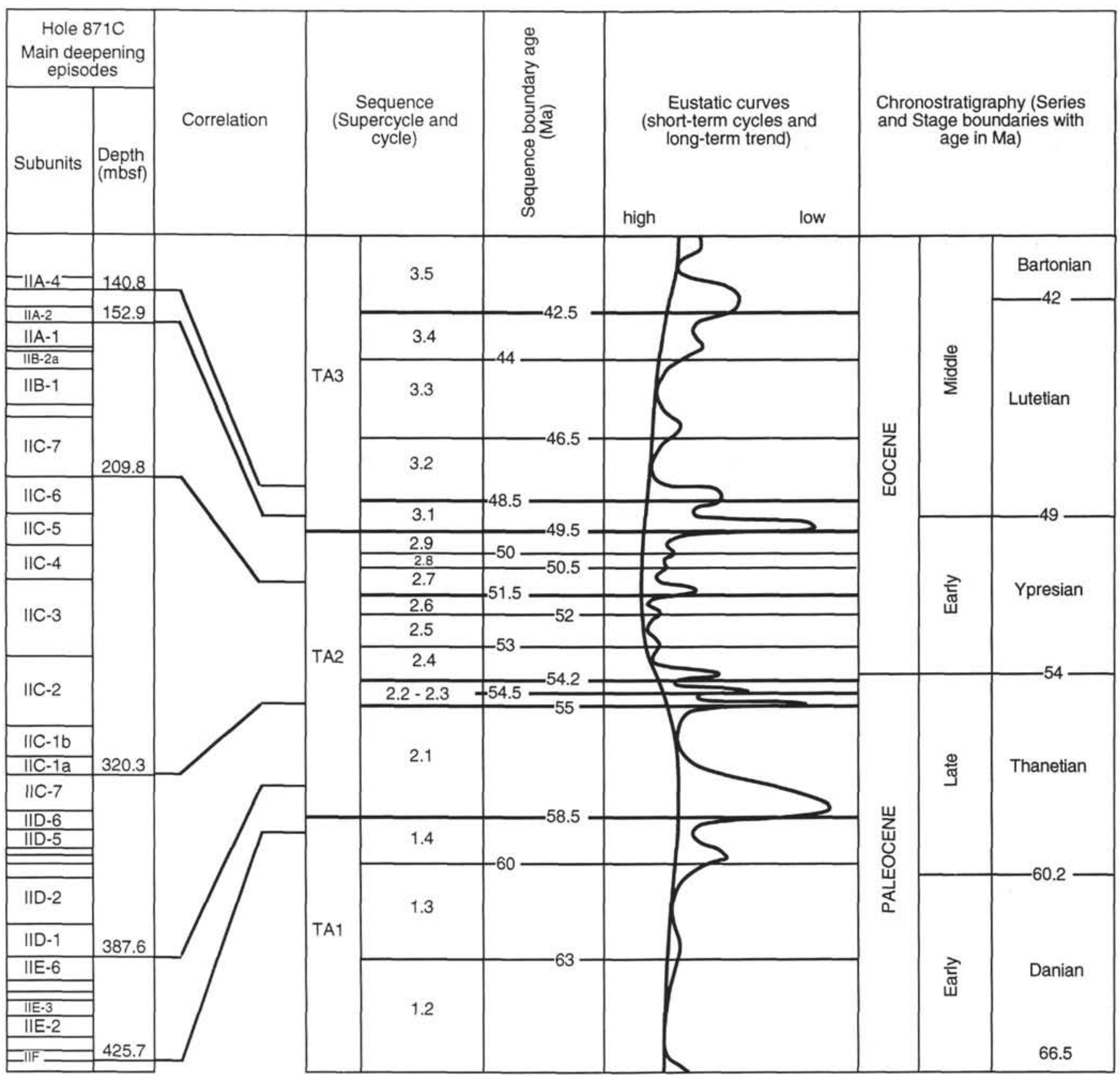

Figure 10. Major deepening episodes in Hole 871C and the Paleocene to middle Eocene portion of the eustatic sea-level curve compiled by Haq et al. (1988). Correlations of deepening episodes in Hole $871 \mathrm{C}$ with major transgressions are constrained by the placement of the Paleocene/Eocene boundary (Table 2).

the Paleocene-Eocene portion of the eustatic sea-level curve of Haq et al. (1988) appears to be a reliable representation of the eustatic sea levels recorded by isolated seamounts in the Pacific.

Some minor sequences in the Haq et al. (1988) compilation also appear to be recorded within the Limalok platform. For example, their set of early Eocene sequences TA 2.4 through TA 2.9 are mainly minor variations except for a single major sea-level excursion in lower TA 2.7 (Fig. 10). This series is correlated to Subunits IIC-2 through IIB-2; which contains one major deepening episode (top of Subunit IIC-6) and at least three minor cycles of deepening-shallowing.

The main discrepancy in the Limalok Guyot stratigraphy correlation to the Haq et al. (1988) curve is at the Paleocene/Eocene boundary. Their curve in the latest Paleocene contains three close-spaced sequences with progressively higher levels of maximum sea level (TA 2.2 to 2.4 ; Fig. 10). These events may correlate to the set of deepening and parasequence events combined into upper Subunit IID-7 and lower Subunit IIC-1; but they cannot be resolved as distinct depositional sequences. This set of end-Paleocene events is also exhibited as a single major excursion on some other margins (e.g., Gräfe, 1994).

\section{Final Stages of Middle Eocene Guyot}

The last stage of active shallow-water carbonate accumulation at Site 871 was an algal-cyanobacterial-rich facies near or at sea level (Fig. 8). This episode is considered to be equivalent to a falling or "lowstand" of eustatic sea level that followed a general upwardshallowing succession of the underlying $\sim 50 \mathrm{~m}$ of facies, from a lagoon to a shallow algal-cyanobacterial-rich facies. The magnitude of the regression in the Haq et al. (1988) curve would imply a period of emergence of the carbonate platform, but there is no direct evi- 
Table 2. Sequence stratigraphy interpretation of carbonate platform succession in Hole 871C and possible correlation to Paleocene-Eocene eustatic sea-level rises and associated ages compiled by Haq et al. (1988).

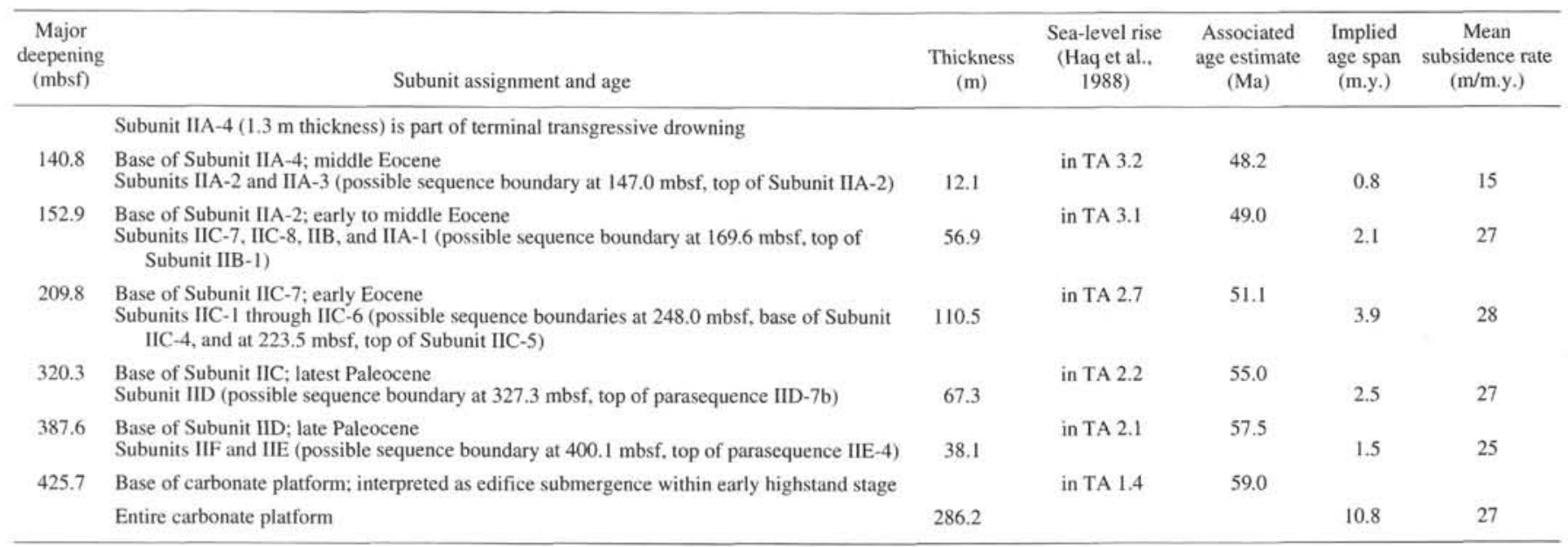

Note: These major sequences contain higher order sequences and parasequences. The numbered Paleocene-Eocene sequences occur in the "Tejas A" (TA) second-order supersequence set of Haq et al. (1988), and the relative ages of the onset of rapid sea-level rise within each sequence is estimated from the shape of their eustatic curve between the bounding sequence boundaries. Their time scale assigns $60.2 \mathrm{Ma}$ to the end of the early Paleocene, $54 \mathrm{Ma}$ to the end of the Paleocene, and $49 \mathrm{Ma}$ to the end of the Early Eocene. The mean subsidence rates assume that each major deepening event is initiated from the same shallow-water depth of deposition and that there is not a significant long-term rise or fall of eustatic sea level superimposed on the sequence set.

dence for an extended exposure. The platform drowned during the following transgressive cycle. However, the drowning process may have involved a two-pulse transgression, with the minor transgressive surface between algal Subunit IIA-1 and lagoonal Subunit IIA-2 representing the first pulse, followed by a thickened upward-shallowing parasequence as relative sea level took a slight dip before the next major deepening phase.

This pattern of two progressive transgressive pulses is also displayed in the Haq et al. (1988) eustatic sea-level curve as earliestmiddle Eocene sequences TA 3.1 and lower 3.2. This is the only major transgression noted in the Eocene portion of their scale, and is drawn as two very rapid sea-level rises separated by a brief lower amplitude fall and lowstand. The second-largest Eocene transgression is at the top of the Lutetian substage of late-middle Eocene (sequence TA 3.5; $42 \mathrm{Ma}$ ). However, this event is not considered a candidate for the terminal drowning of the guyot, because it would imply that the Eocene portion of the carbonate platform had an unacceptably slow subsidence rate of only $14 \mathrm{~m} / \mathrm{m}$.y. Therefore, best estimate for the drowning of the platform drowning is the two-stage major transgression in the earliest middle Eocene.

\section{Drowning of Guyot Carbonate Platforms}

The drowning of a carbonate atoll or bank appears to involve multiple factors acting in conjunction. Essentially, the carbonate factory may be able to handle one crisis, but it is overwhelmed when simultaneously flooded, overheated, and overfed. These interactions can be seen in the detailed stratigraphy and general paleoclimategeographic conditions associated with the four independent guyots of Limalok (middle Eocene drowning), Wodejebato (Maastrichtian drowning), Takuyo-Daisan (Albian drowning), and MIT (late Albian drowning). These four guyots have important similarities in the events and conditions associated with their demise.

A common precursor is a significant lowstand in sea level, during which the continued upward growth of the carbonate system produces a flattened bank at sea level with a widespread algal-rich intertidal facies. This shallow-water phase follows a previous prolonged slow transgression and highstand facies. The transgressive to highstand phase produced an upward-growing carbonate system of "atoll" morphology, consisting of a lagoon behind a shoal complex produced by debris from a seaward "carbonate factory" of corals, algals, rudists, and other organisms. The overlying shallow-water phase is a "flat- topped bank" morphology produced by infilling of the former lagoon by storm-redeposited rubble, and is capped by quasi-emergent algalflat facies. The shift from the lagoon phase to this shallow-water phase is very rapid. This rapid shallowing episode may incorporate a "sequence boundary," during which the rate of eustatic sea-level fall reaches a maximum. A rate of eustatic sea-level fall of $\sim 3-4 \mathrm{~m}$ per $100,000 \mathrm{yr}$ effectively offsets the rate of seamount subsidence. A more rapid rate of sea-level fall produces surfaces of emergence on the guyot platform. This sequence-boundary episode is followed by the ensuing "lowstand," when eustatic sea level continues to fall at a slowing rate until it attains an eventual stillstand. During this interval of falling eustatic sea level, accommodation space, both within the "lagoon" and in the seaward active carbonate factory, is forming slower than during stillstands or transgressive pulses. Therefore, the infilling of the lagoon is probably accompanied by a seaward prograding of the carbonate factory and shoal complex. Eventually, the outward progradation will be constrained when the outer debris apron becomes oversteepened, and the carbonate factory will become reduced in width. This environmental limitation of the carbonate factory area was crucial to the Albian and Maastrichtian banks, in which the assemblage of isolated corals, algal clusters, and rudists did not produce a wave-resistant bulwark of framestone, but rather appeared to maintain continued upward growth of the platform merely by overproduction of bioclastic debris to be washed into outer shoals and the interior bank (e.g., Grötsch, 1994). Even Tertiary "reefs" resemble a bioclastic "garbage pile" more than an "in-place framework" (Hubbard et al., 1990, cited in Grötsch, 1994). Therefore, when sea level begins to rise after the eustatic lowstand, this constricted band of excess bioclastic debris may not be able to expand its areal extent and associated upward growth of its debris shelf to maintain an aggregate upward accumulation of the entire guyot platform system.

The inhibited development of the carbonate bank during "lowstand" is followed by a major transgression. The transgressive series is commonly initiated by a subduced parasequence pulse, then accelerates as the transgressive phase of each succeeding parasequence is superimposed on the general deepening trend. The carbonate factory, which had been constricted to a narrow bench around the steepened flat-topped bank, can only back-step a small distance before it is on the highest point of the bank surface. The creation of new bioclastic debris is insufficient to build up a sufficient shoal complex for the carbonate-factory bench to continue back-stepping to maintain favorable depths for its associated "zooxanthellae" symbionts. The back- 
stepping is further constrained by the competition with algal mats. The guyot platform has a transgressive deepening stage recorded in the final carbonate facies before the system completely drowns. The observed guyot-drowning transgressions appear to be major and rapid events in the sequence-stratigraphy charts compiled by the Exxon group: for example, the late Albian, mid-Maastrichtian, and early-middle Eocene events are pronounced global events. However, the magnitude of the transgressive rise is only one factor in platform drowning. Transgressions of nearly comparable magnitude are recorded, successfully, by the survival of carbonate platforms through the Aptian and across the Paleocene/Eocene boundary. Another important factor is the rate of the cumulative transgressive rise. For example, transgressive rises of similar magnitudes occur in the late Paleocene (sequence TA 2.1) and latest Paleocene (sequence TA 3.1). In the Haq et al. (1988) charts; however, the earlier sea-level rise was a gradual process over approximately $1.5 \mathrm{~m} . \mathrm{y}$., whereas the later transgressive event spanned less than 0.2 m.y (Fig. 10). The final drowning may incorporate a longer term transgressive rise enhanced periodically by superposition of an independent parasequence rise. Other important and required factors in carbonate platform drowning appear to be an extended "lowstand" interval and associated formation of a flattened carbonate platform and a set of unfavorable environmental conditions.

A brief but major sea-level excursion, such as the estimated $200,000 \mathrm{yr}$ duration to the composite succession of a major sequence boundary, lowstand, and rapid transgression in the latest Paleocene (lower portion of sequence TA 2.2 of Haq et al., 54.8-55.0 Ma) does not allow sufficient time for accumulation of significant subsidence of the seamount. At a typical subsidence rate of $30 \mathrm{~m} / \mathrm{m}$.y., such an excursion, while deadly to the ecosystems in the short-term, would produce a net deepening of only about $6 \mathrm{~m}$. Therefore, the carbonate platform will become recolonized after this transgression, and the system will recover in a short time. Similar dramatic short-term excursions, but with inadequate duration to permanently drown carbonate platforms, characterize the Pleistocene glacial-interglacial cycles. In contrast, the rapid earliest middle Eocene major transgression occurred nearly 1.3 m.y. after the previous major sea-level drop (transgression of sequence TA 3.2 at 48.2 Ma was a return to conditions before the basal TA 3.1 sequence-boundary regression at 49.5 Ma). Therefore, a subsidence "deficit" of approximately $40 \mathrm{~m}$ had accumulated. This added deepening caused by subsidence, when added to the rapid rise of sea level, overwhelmed the ability of the carbonate factory to become reestablished.

Upward-shallowing successions produced by Milankovitchrelated sea-level oscillations are present in all systems tracts. These oscillations cause periodic accelerations and slowing episodes superimposed on the longer term trends in sea level. The magnitude of these Milankovitch-induced oscillations of sea level in nonglacial intervals is probably equivalent to the combined effect of ocean thermohaline volume changes $(0.1-10 \mathrm{~m}$, depending upon the magnitude of cyclical heating and cooling of deep ocean waters) and postulated changes in groundwater storage on the continents (up to 10-20 m) (Revelle, 1990; Hay and Leslie, 1990; Plint et al., 1992). During stillstands or periods of falling sea level, these Milankovitchcycle oscillations of global sea level will produce a series of stacked, condensed, upward-shallowing successions or parasequences. During long-term transgressions, these oscillations produce rapid upward pulses of sea level interspersed with relative stillstands.

The carbonate sediments may become dominated by algae. At Wodejebato Guyot, the Maastrichtian "inner perimeter ridge" at Site 874 is capped by a unique stromatoporoid-algal-coral assemblage (Camoin et al., this volume); however, the "lagoonal" setting at Site 873 only recorded storm-rubble debris accumulation without a significant final stage dominated by algal facies (Lincoln et al., this volume). At Site 878 on MIT Guyot, the Albian "lagoonal" setting is also dominated by algal flats in the upper portion (Ogg, this volume). At Site 871, the Eocene "lagoon" shallowed into possible algal flat intervals, according to the features in FMS imagery and the associated elevated uranium concentrations; however, an unusual algalenrichment in the uppermost portion of the succession was not noted in the cores or in the downhole logs. The abundance of algal flats or stromatoporoids may be enhanced by increased nutrient availability, a phenomenon observed in present-day Caribbean reefs ("nutrient poisoning" condition of Schlager, 1989). Vogt (1989) proposed that excess nutrient episodes were a major contributing factor to the drowning of mid-Cretaceous guyot platforms. The high-fertility waters of the equatorial divergence zone would contribute to an increase in nutrient availability, and it is a curious correlation that all the guyots drilled on Leg 144 preferentially drowned when approaching this equatorial zone. Another factor favoring algal growth may have been their tolerance relative to other carbonate-producing organism under conditions of heavy rainfall mixed with high evaporation rates in the tropical waters under the Intertropical Convergence Zone (ITCZ). Menard (1982) noted the apparent correlation between "healthy" atoll-reef systems in the nonequatorial regions, contrasted with "nonhealthy" atoll-reefs in proximity to the equator, which he also associated with rainfall and evaporation patterns. Under such variable climatic extremes, especially those affecting the salinity of shallow semirestricted waters, algae are probably more tolerant than are other large carbonate producers. However, an abundance of algal growths can be a deathknell to a carbonate factory because these will prevent attachment or even smother other sessile organisms. This end effect of "nutrient poisoning" is the inability of a carbonate factory to continue to produce sufficient bioclasts to maintain an upward growth of the larger platform during the combination of subsidence and rising sea levels.

The final environmental factor, which is based on the observed correlation of preferential drownings with global paleoclimatic trends, is a period of enhanced global warmth. The Albian and midMaastrichtian are the warmest periods during the Pacific Cretaceous platform developments (there are no carbonate platforms known in the Pacific during the even warmer Cenomanian-Santonian), and the middle Eocene is the warmest interval of the Tertiary. In present Pacific reefs, El Niño events of anomalous warming produce widespread coral bleaching (inability of the corals to retain zooxanthellae in their tissues). The production of carbonate skeletal material ceases, and the reef ecosystem is destroyed. The reefs around the Galapagos Islands were essentially permanently destroyed by the 1982-1983 El Niño. Based upon the El Niño analogy, geological periods of enhanced warmth may be less favorable for continuous "healthy" carbonate platform growth. In this regard, it is interesting that all the Leg 144 guyots drowned during their approach to the paleo-equator, which may represent both the warmest waters in the Pacific in these regions and the region with greatest susceptibility to El Niño anomalous warming episodes. Certainly, the observed combination of "hot" geological paleoclimates, plus proximity to the paleo-equator, plus the probable periodic occurrence of anomalous warming episodes in the tropical Pacific associated with such El Niño-Southern Oscillations would represent the worst possible climatic condition for a carbonate factory based on symbionts (e.g., corals, rudists, possibly red algae) to maintain the active upward growth necessary to keep pace with a rapidly rising sea level.

A carbonate platform system may be able to survive exposure to any of these factors individually, but when four or five of these conditions act in devastating harmony, then the guyot will sink below the waves, leaving behind only an enigma for future marine geologists.

\section{ACKNOWLEDGMENTS}

This research was sponsored by the Ocean Drilling Program and USSAC. Many of our interpretations of the depositional history are based upon the observations and presentations by our shipboard colleagues. Kai-Uwe Gräfe provided advice and an advance copies of his studies on carbonate platform sequences and Paleocene-Eocene sea-level changes, and a valuable review and critique. Gabi Ogg 
drafted key figures and aided production of the manuscript versions. Valuable reviews and critiques were provided by Kai-Uwe Gräfe and an anonymous reviewer.

\section{REFERENCES*}

Asquith, G.D., 1979. Subsurface Carbonate Depositional Models: A Concise Review: Tulsa, OK (Petroleum Publ. Co.).

Bourke, L., Delfiner, P., Trouiller, J.-C., Fett, T., Grace, M., Luthi, S., Serra, O., and Standen, E., 1989. Using Formation MicroScanner images. Tech. Rev., 37:16-40.

Cooper, P., Arnaud, H.M., and Flood, P.G., 1995. Formation MicroScanner logging responses to lithology in guyot carbonate platforms and their implications: Sites 865 and 866. In Winterer, E.L., Sager, W.W., Firth, J.V., and Sinton, J.M. (Eds.), Proc. ODP, Sci. Results, 143: College Station, TX (Ocean Drilling Program), 329-372.

Detrick, R.S., and Crough, S.T., 1978. Island subsidence, hot spots, and lithospheric thinning. J. Geophys. Res., 83:1236-1244.

Dorfman, M.H., Newey, J.-J., and Coates, G.R., 1990. New techniques in lithofacies determination and permeability prediction in carbontes using well logs. In Hurst, A., Lovell, M.A., and Morton, A.C. (Eds.), Geological Applications of Wireline Logs. Geol. Soc. Spec. Publ. London, 48:113120.

Drummond, C.N., and Wilkinson, B.H., 1993a. Aperiodic accumulation of cyclic peritidal carbonate. Geology, 21:1023-1026.

1993b. On the use of cycle thickness diagrams as records of long-term sealevel change during accumulation of carbonate sequences. $J$. Geol., 101:687-702.

Ekstrom, M.P., Dahan, C.A., Chen, M.-Y., Lloyd, P.M., and Rossi, D.J., 1986. Formation imaging with microelectrical scanning arrays. Trans. SPWLA Annu. Logging Symp., 27:Pap. BB.

Goldhammer, R.K., Dunn, P.A., and Hardie, L.A., 1990. Depositional cycles, composite sea-level changes, cycle stacking patterns, and the hierarchy of stratigraphic forcing: examples from Alpine Triassic platform carbonates. Geol. Soc. Am. Bull., 102:535-562.

Goldhammer, R.K., Lehmann, P.J., and Dunn, P.A., 1993. The origin of high-frequency platform carbonate cycles and third-order sequences (Lower Ordovician El Paso Gp, west Texas): constraints from outcrop data and stratigraphic modeling. J. Sediment. Petrol., 63:318-359.

Gräfe, K.-U., 1994. Sequence stratigraphy in the Cretaceous and Paleogene (Aptian to Eocene) of the Basco-Cantabrian Basin (N. Spain). Tub. Geowiss. Arbeiten, Reihe A, 18

Gräfe, K.-U., and Wiedmann, J., 1993. Sequence stratigraphy in the Upper Cretaceous of the Basco-Cantabrian Basin (northern Spain), Geol. Rundsch., 82:327-361

Grötsch, J., 1994. Guilds, cycles and episodic vertical aggradation of a reef (late Barremian to early Aptian, Dinaric carbonate platform, Slovenia). Spec. Publ. Int. Assoc. Sedimentol., 19:227-242.

Haq, B.U., Hardenbol, J., and Vail, P.R., 1988. Mesozoic and Cenozoic chronostratigraphy and cycles of sea-level change. In Wilgus, C.K., Hastings, B.S., Kendall, C.G.St.C., Posamentier, H.W., Ross, C.A., and Van Wagoner, J.C. (Eds.), Sea-level Changes-An Integrated Approach. Spec. Publ.-Soc. Econ. Paleontol. Mineral., 42:72-108.

Harker, S.D., McGann, G.J., Bourke, L.T., and Adams, J.T., 1990. Methodology of Formation Micro Scanner image interpretation in Claymore and Scapa Fields (North Sea). In Hurst, A., Lovell, M.A., and Morton, A.C. (Eds.), Geological Applications of Wireline Logs. Geol. Soc. Spec. Publ. London, 48:11-25.

Hay, W.W., and Leslie, M.A., 1990. Could possible changes in global groundwater reservoir cause eustatic sea-level fluctuations? In Revelle, R. (Ed.), Sea Level Change. Nat. Res. Counc., Stud. Geophys., 161-170.

Hubbard, D.K., Miller, A.I., and Scaturo, D., 1990. Production and cycling of calcium carbonate in a shelf-edge reef system (St. Croix, U.S. Virgin Islands): applications to the nature of reef systems in the fossil record. $J$. Sediment. Petrol., 60:335-360.

Jones, B., and Desrochers, A., 1992. Shallow platform carbonates. In Walker R.G., and James, N.P. (Eds), Facies Models: Response to Sea Level Change. Geol. Assoc. Can., 277-301.

Lincoln, J.M., Pringle, M.S., and Premoli-Silva, I., 1993. Early and Late Cretaceous volcanism and reef-building in the Marshall Islands. In Pringle, M.S., Sager, W.W., Sliter, W.V., and Stein, S. (Eds.), The Mesozoic Pacific: Geology, Tectonics, and Volcanism. Geophys. Monogr., Am. Geophys. Union, 77:279-305.
Lincoln, J.M., and Schlanger, S.O., 1991. Atoll stratigraphy as a record of sea level change: problems and prospects. J. Geophys. Res., 96:6727-6752.

.Menard, H.W., 1982. The influence of rainfall upon the morphology and distribution of atolls. In Scrutton, R.A., and Talwani, M. (Eds.), The Ocean Floor: Bruce Heezen Commemorative Volume: Chichester (Wiley), 305 311.

Molinie, A.J., and Ogg, J.G., 1992a. Formation microscanner imagery of Lower Cretaceous and Jurassic sediments from the western Pacific (Site 801). In Larson, R.L., Lancelot, Y., et al., Proc. ODP, Sci. Results, 129: College Station, TX (Ocean Drilling Program), 671-691.

, 1992b. Milankovitch cycles in Upper Jurassic and Lower Cretaceous radiolarites of the equatorial Pacific: spectral analysis and sedimentation rate curves. In Larson, R.L., Lancelot, Y., et al., Proc. ODP, Sci. Results, 129: College Station, TX (Ocean Drilling Program), 529-547.

Osleger, D., 1991. Subtidal carbonate cycles: implications for allocyclic vs. autocyclic controls. Geology, 19:917-920.

Osleger, D., and Read, J.F., 1993. Comparative analysis of methods used to define eustatic variation in outcrop: Late Cambrian interbasinal sequence development. Am. J. Sci., 293:157-216.

Pezard, P., and Luthi, S., 1988. Borehole electrical images in the basement of the Cajon Pass Scientific drillhole, California: fracture identification and tectonic implications. Geophys. Res. Lett., 15:1017-1020.

Pezard, P.A., Lovell, M., and Ocean Drilling Program Leg 126 Shipboard Scientific Party, 1990. Downhole images - electrical scanning reveals the nature of subsurface oceanic crust. Eos, 71:710.

Plint, A.G., Eyles, N., Eyles, C., and Walker, R.G., 1992. Control of sea-level change. In Walker, R.G., and James, N.P. (Eds.), Facies Models: Response to Sea Level Change. Geol. Assoc. Can., 15-25.

Pratt, B.R., James, N.P., and Cowan, C.A., 1992. Pertidal carbonates. In Walker, R.G., and James, N.P. (Eds.), Facies Models: Response to Sea Level Change. Geol. Assoc. Canada, 303-322.

Premoli Silva, I., Haggerty, J., Rack, F., et al., 1993. Proc. ODP, Init. Repts., 144: College Station, TX (Ocean Drilling Program).

Revelle, R. (Ed.), 1990. Sea Level Change. Nat. Res. Counc., Stud. Geophys. Schlager, W., 1989. Drowning unconformities on carbonate platforms. In Wilgus, C.K., Hastings, B.S., Kendall, C.S., Posamentier, H.W., Ross, C.A., and van Wagoner, J.C. (Eds.), Sea Level Changes-An Integrated Approach. Spec. Publ.-Soc. Econ. Paleontol. Mineral., 42:15-25.

Serra, O., 1985. Shallow-water carbonate environment (Sect. 5.8). In Sedimentary Environments from Wireline Logs: Houston (Schlumberger Educ. Services), 143-154.

Shipboard Scientific Party, 1993. Site 871. In Premoli Silva, I., Haggerty, J., Rack, F., et al., Proc. ODP, Init. Repts., 144: College Station, TX (Ocean Drilling Program), 41-103.

Tucker, M.E., and Wright, P.V., 1990. Carbonate Sedimentology: Oxford (Blackwell Sci. Publ.).

Van Wagoner, J.C., Mitchum, R.M., Campion, K.M., and Rahmanian, V.D., 1990. Siliciclastic Sequence Stratigraphy in Well Logs, Cores, and Outcrops: Concepts for High-Resolution Correlation of Time and Facies. AAPG Methods Explor. Ser., 7.

Vogt, P.R., 1989. Volcanogenic upwelling of anoxic, nutrient-rich water: a possible factor in carbonate-bank/reef demise and benthic faunal extinctions? Geol. Soc. Am. Bull., 101:1225-1245.

Watts, A.B., and Ribe, N.M., 1984. On geoid heights and flexure of the lithosphere at seamounts. J. Geophys. Res., 89:11152-11170.

Wilson, J.L., 1975. Carbonate Facies in Geologic History: Berlin (SpringerVerlag).

Wolfe, C.J., and McNutt, M.K., 1991. Compensation of Cretaceous guyots of the Darwin Rise, northwest Pacific Ocean. J. Geophys. Res., 86:23632374.

\footnotetext{
Abbreviations for names of organizations and publications in ODP reference lists follow the style given in Chemical Abstracts Service Source Index (published by American
} Chemical Society)

Date of initial receipt: 4 February 1994

Date of acceptance: 14 October 1994

Ms 144SR-042 


\section{APPENDIX}

\section{Description and Interpretation of Facies Subunits}

The following summary of the carbonate facies integrates the independent observations from the cored sediments (typically much less than $50 \mathrm{~cm}$ of recovery from each 10 - $\mathrm{m}$ cored interval), the quantitative resistivity measurements, the natural gamma-ray intensities, and the detailed FMS "textures" and vertical successions. Division of the lithologic succession into subunits is based initially upon the facies and nomenclature of shipboard-defined lithologic units. At Site 871, the entire carbonate platform succession was denoted as lithologic Unit II with six lettered subunits. Additional subdivisions are defined according to coherent log-facies packets or individual recognized parasequences (Fig. 1). These subunits simplify later discussions of sedimentary history interpretation.

Relative FMS resistivity (darkness on gray-scale imagery) is expressed in a shorthand of "low" ( $<2 \Omega \mathrm{m})$, "medium" $(2-5 \Omega \mathrm{m})$, and "high" $(>5 \Omega \mathrm{m})$ resistivity. Relative resistivity of features produced in the dynamic-processed enhanced FMS imagery denoted as "higher" or "lower" resistivity, and do not imply fixed resistivity ranges. In the accompanying log-stratigraphy columns, the resistivity values from shallow-focused resistivity tool (SFLU instrument) are plotted after depth-shifting to FMS depths. Some features on this resistivity $\log$ (resolution of $1 \mathrm{~m}$ ) have been adjusted by increasing or decreasing the sharpness and amplitude of peaks to agree with the high-resolution resistivity records of the FMS imagery (resolution of $2.5 \mathrm{~mm}$ ).

All depths of features and subunits, except quoted cored intervals, refer to the FMS logs as processed by Lamont-BRG or corrected depths on the other downhole logs (see main text).

\section{Lithologic Unit III \\ Clay Overlying Basalt \\ (425.7-451.6 mbsf, $25.9 \mathrm{~m}$ thickness)}

Core 144-871C-32R (422.5-432.2 mbsf, 6.1 m recovery): clay, mottled olive gray to dark red; overlain at Section 1, $40 \mathrm{~cm}$, by dark gray skeletal packstone

\section{Summary of Logging Facies}

426.0-425.7 mbsf: Top of clay (lithologic Unit III). The FMS resistivity tool penetrated to a depth of 426 mbsf and may have recorded the top of the clay of lithologic Unit III as the top of a very low resistivity unit extending upward to $425.7 \mathrm{mbsf}$ (Fig. 1). This placement of the top of the clay at 425.7 mbsf is supported by the geochemical tool, which indicates a sharp increase in the aluminum and iron indicator ratio and a corresponding decrease in calcium below $423 \mathrm{mbsf}$. However, the $424-\mathrm{mbsf}$ level is at the deepest depth limit of the geochemical tool record; therefore, these signals may be influenced by the $0.5-\mathrm{m}$ resolution of the tool.

\section{Lithologic Subunit IIF}

Dark Gray Foraminifer-Mollusk Packstone, with Abundant Miliolids, Mollusks, Carbon Fragments, and Pyrite (421.9-425.7 mbsf, $3.8 \mathrm{~m}$ thickness, late Paleocene)

Core $144-871 C-32 R$ (422.5-432.2 mbsf, $6.1 \mathrm{~m}$ recovery): dark gray skeletal packstone above Section $1,40 \mathrm{~cm}$, of thick-walled mollusk fragments, gastropods, and common foraminifers (alveolinids, miliolids, nummulites), coarse-grained and poorly sorted

Core 144-87IC-3IR (412.8-422.5 mbsf, $0.4 \mathrm{~m}$ recovery): dark gray packstone of miliolids and mollusks below Section 1, 21 cm, very coarse grained and poorly sorted; upper $6 \mathrm{~cm}$ of recovered portion is yellowish colored; overlain by tan-colored algal grainstone with rhodoliths

\section{Summary of Logging Facies}

425.7 mbsf: Base of carbonate platform. We place the base of the carbonate platform (lithologic Unit II) at $425.7 \mathrm{mbsf}$. The contact to the overlying high-resistivity carbonate facies is very sharp, although this boundary may have been enhanced by later diagenesis.

421.9-425.7 mbsf: Very high-resistivity, 3.8-m interval with a single, very low-resistivity, $20-\mathrm{cm}$ bed at $424.4-424.6 \mathrm{mbsf}$. There is a progressive upward trend toward higher resistivity. Dynamic FMS imagery indicates that this interval is medium bedded (approximately seven beds) with thin $(\sim 5-10 \mathrm{~cm})$ interbeds of relatively lower resistivity lithology. On the dynamic FMS im- agery this bedding is most pronounced and regular in the lower $2 \mathrm{~m}$ of the unit, whereas the relatively lower resistivity interbeds in the upper portion are not as well defined and appear to be wavy or discontinuous. An upward decrease occurs in the iron-indicator ratio and in aluminum, whereas calcium progressively increases. This suggests an upward decrease in clay content, probably derived from exposures of the claystone facies. In contrast to the shipboard reports of pyrite, no apparent change takes place in the sulfur content relative to the overlying units.

Interpretation: The lower boundary of the carbonate platform is a flooding surface on the muddy near-shore margin of a weathered volcanic edifice. The lowermost facies is a medium-bedded, poorly sorted carbonate sand, comprised primarily of foraminifer and mollusk fragments. The bioclast assemblage suggests redeposition from an original "lagoonal" environment. Clay and organic material continued to be intermixed into these beds, but in decreasing amounts. The dark gray coloration, the result of a combination of fine organic material and pyrite, indicates a low-oxygen, post-burial environment. A storm-bed origin for these beds, possibly followed by some bioturbation mixing, is suggested by the apparent pulse deposition followed by establishment of anaerobic conditions within the beds, medium-bedding of homogeneous, poorly sorted or vaguely upward-fining packstone, and intermixed clay. The shipboard sedimentology report indicates that lithologic Subunit IIF is coarse grained at its base and becomes finer grained toward the top, where it has less than $2 \%$ porosity (Shipboard Scientific Party, 1993). This upward-fining trend may partially cause the upward increase in resistivity. The top of this 3.8-m unit was emergent, as indicated by the yellowish limonite weathering.

This packet of dark gray packstone beds represents a transgressivehighstand facies, terminated by a drop in relative sea level. The transgression may be a local feature related to the subsidence of the volcanic edifice, rather than caused by a significant eustatic sea-level rise. However, the emergent surface overlain by an algal grainstone facies requires a significant drop of sea level. The entire 3.8-m unit could be considered as a parasequence within a general transgressive or early highstand systems tract, rather than as a separate sequence.

\section{Lithologic Subunit IIE \\ Rhodolith Grainstone and Packstone, with Abundant Red-algal Fragments (387.7-421.9 mbsf, 34.2 m thickness, late Paleocene)}

\section{Summary of Logging Facies}

This algal-rich Subunit IIE is characterized by high natural gamma-ray intensity and by a sawtooth pattern of six main cycles or parasequences of upward-increasing resistivity (Fig. 1). Each parasequences displays a progressive upward increase in resistivity, terminating sharply in the relatively lowresistivity zone at the base of the next parasequence (Fig. 3). These parasequences average about $5 \mathrm{~m}$ in thickness and commonly display an internal structure of irregular meter-thick zones of relatively higher or lower resistivity fluctuations superimposed on the general upward trend toward higher resistivity. Peaks in uranium concentration occur just below the highest resistivity, uppermost surface of each parasequences. The higher parasequences are thinner than the lower cycles, with the uppermost compound cycle consisting of four distinct pulses. These six major parasequences are designated as logging facies Subunits IIE-1 through IIE-6.

The general uranium enrichment of Subunit IIE is probably associated with algal-rich intervals in these beds, caused by the redox scavenging of uranium from seawater in the reducing microenvironments of algal films (Serra, 1985). However, another process that may contribute to the uranium enrichment is condensed sedimentation.

The top of Subunit IIE was placed at $387.6 \mathrm{mbsf}$ at the sharp lower boundary of a 35 -m-thick, low-resistivity interval. The overlying unit lacks high-amplitude parasequences and has a low natural gamma-ray intensity, although the lowest $10 \mathrm{~m}$ contains another sawtooth peak of uranium concentration. This boundary placement from the logging characteristics is significantly lower than the 374.3-mbsf level assigned by shipboard sedimentologists from the limited core recovery.

Subunit IIE represents a late highstand systems tract followed by an episode when falling sea levels partially kept pace with seamount subsidence rates. A "sequence boundary" or level of maximum rates of falling eustatic sea level, could be assigned to $400.1 \mathrm{mbsf}$. This level is a surface of emergence and marks the change between a lower interval of pronounced development of 5-m-thick parasequences (typical of highstand facies) to an upper interval dominated by algal flats and thin parasequence before the next drowning episode. 
Logging Facies Subunit IIE-1

(416.7-421.9 mbsf, $5.2 \mathrm{~m}$ thickness)

Core 144-871C-31R (412.8-422.5 mbsf, $0.4 \mathrm{~m}$ recovery): foraminiferalgal grainstone, above Section 1, $21 \mathrm{~cm}$, well sorted and coarse grained, with red-algal rhodoliths up to $1-\mathrm{cm}$ diameter; overlain by bioturbated, gastropod-mold-rich wackestone

416.7-421.9 mbsf: Above the sharp, very high-resistivity top of Subunit IIF at 421.9 mbsf is a 1.5 -m-thick interval of medium to high resistivity that displays about $10 \%-20 \%$ of equant, high-resistivity balls of 5 - to $10-\mathrm{cm}$ diameter in the FMS imagery. This nonbedded facies probably consists of algalrhodoliths within a less cemented grainstone. This facies passes gradationally upward into a high-resistivity interval from about 420.2 to 418.0 mbsf, which, in addition to the high-resistivity ?rhodolith balls, contains about $5 \%-10 \%$ of lenticular to quasiplanar patches, 10 to $20 \mathrm{~cm}$ thick and of low to medium resistivity. Following a $0.6-\mathrm{m}$ interval of relatively lower resistivity, the sequence terminates in a 0.7 -m-thick bed ( $417.4-416.7 \mathrm{mbsf})$ of high resistivity.

Interpretation: A flooding surface at the base is followed by upwardshallowing grainstone with red-algal rhodoliths and flattened algal biscuits. The parasequence was terminated by another deepening pulse.

Logging Facies Subunit IIE-2

(409.1-416.7 mbsf, $7.6 \mathrm{~m}$ thickness)

409.1-416.7 mbsf: The lower $3 \mathrm{~m}$ is dominated by medium resistivity, but has four to five bands of relatively higher resistivity apparent in the dynamicprocessed FMS imagery. "Rhodolith"-ball features are absent until $413.0 \mathrm{mbsf}$. A rapid upward increase in resistivity also begins at $413.0 \mathrm{mbsf}$, and peaks in a very high-resistivity zone at $412.0-411.0 \mathrm{mbsf}$. The uppermost $2 \mathrm{~m}$ have mottles of low resistivity (cavities?) within a high-resistivity interval; the unit terminates in a sharp surface at 409.1 mbsf.

Interpretation: The lower portion may correspond to the leached gastropod wackestone recovered at the top of Core 144-871C-31R. An upward-shallowing succession passes into algal-rich facies, capped by a well-cemented bed with possible solution features. The upper surface may have been emergent during the cementation episode, before the drowning by the next parasequence basal transgression.

Logging Facies Subunit IIE-3

(403.1-409.1 mbsf, $6.0 \mathrm{~m}$ thickness)

Core 144-87IC-30R (403.1-412.8 mbsf, $1.3 \mathrm{~m}$ recovery): algal-coralbivalve-gastropod packstone coarsening upward to algal-rich rudstone to grainstone

403.1-409.1 mbsf: The basal $1.7 \mathrm{~m}$ consists of a homogeneous low-resistivity facies without "rhodolith"-ball features. The interval from 405.6 to 407.4 mbsf is composed of thin-bedded $(10-15 \mathrm{~cm})$ alternations of medium- and high-resistivity lithology, with an associated peak in natural gamma-ray intensity. The uppermost $1.5 \mathrm{~m}$ is high resistivity with irregular thin beds and a sharp upper surface.

Interpretation: This is a parasequence of packstone, which coarsens upward to algal-rich grainstone and terminates in a deepening surface.

\section{Logging Facies Subunit IIE-4}

(400.1-403.1 mbsf, $3.0 \mathrm{~m}$ thickness)

400.1-403.1 mbsf: Rapid upward increase from a basal $1.3 \mathrm{~m}$ of low resistivity to a major high-resistivity peak. Sharp upper surface. High natural gamma-ray intensity associated with middle portion.

Interpretation: The first set of parasequences culminates in this high-amplitude, condensed parasequence. The top surface was possibly emergent. In contrast, the tops of the overlying parasequences of Subunits IIE-5 and IIE-6 are not sharp surfaces (Fig. 3) suggesting that these cycles were not developed in as shallow to emergent depths as this Subunit IIE-4. Accumulation of these overlying parasequences appear to limited by subsidence being partially cancelled by a dropping sea level. Therefore, the rapid shift between the well-developed parasequences of Subunits IIE-1 through IIE-4 to the "condensed" overlying cycles is considered to represent a "sequence boundary," in which the a rapid upward-shallowing was induced by a relative sea-level fall.
Logging Facies Subunit IIE-5

(396.0-400.1 mbsf, $4.1 \mathrm{~m}$ thickness)

Core 144-871C-29R (393.4-403.1 mbsf, 0.3 m recovery): algal packstone with rhodoliths; overlain by a $5-\mathrm{cm}$ piece of foraminifer-peloid grainstone (which may be downhole contamination)

396.0-400.1 mbsf: Basal $1.7 \mathrm{~m}$ is homogeneous, low resistivity grainstone-texture with "rhodolith"-ball features. The upper $2.4 \mathrm{~m}$ has five alternations of medium- and high-resistivity beds or lenses. High natural gamma-ray intensity throughout.

Interpretation: This parasequence is primarily in algal-rich lithologies of rhodolith-grainstone changing upward to a facies with possible algal-cyanobacterial mats.

Logging Facies Subunit IIE-6

(387.6-396.0 mbsf, $8.4 \mathrm{~m}$ thickness)

Core 144-87IC-28R (383.7-393.4 mbsf, $1.2 \mathrm{~m}$ recovery): red-algal grainstone with rhodoliths, benthic foraminifers, coral, and other skeletal fragments

This subunit has four distinct peaks of high resistivity, separated by lowto medium-resistivity facies (Fig. 3). The entire interval has continuous high natural gamma-ray intensity with minor peaks corresponding to the higher resistivity beds. The abundance of "rhodolith"-ball features in the dynamic FMS imagery increases with each higher and (?) coarser grained cycle.

393.0-396.0 mbsf: Lower 1.8-m interval with "rhodolith"-ball features, followed by a rapid upward increase to 40 -cm-thick peak of high resistivity.

391.6-393.0 mbsf: Second thin cycle from medium resistivity upward to $80-\mathrm{cm}$-thick bed of high resistivity.

389.8-391.6 mbsf: Third thin cycle, with the upper 20-cm-thick bed of high resistivity followed by a $10-\mathrm{cm}$ transition interval into the lower resistivity base of the next cycle.

387.6-389.8 mbsf: Fourth cycle is capped by a 1.0-m-thick, rhodolith-rich bed with a sharp upper surface (Fig. 3).

Interpretation: These thin parasequences are developed in an algal-grainstone to a setting with possible algal-cyanobacterial mats.

\section{Lithologic Subunit IID \\ Foraminifer Packstone and Algal-coral Grainstone (320.3-387.7 mbsf, 67.4 m thickness, late Paleocene)}

\section{Summary of Logging Facies}

The lower $34 \mathrm{~m}$ of Subunit IID consists of sustained low- to mediumresistivity lagoonal facies (mainly foraminifer-peloid packstone) within a widened borehole (Fig. 3). There is a progressive upward increase in resistivity, with a thick peak in natural gamma-ray intensity in the middle at $375.2 \mathrm{mbsf}$ corresponding to an algal-rich interval (division between Subunits IID-1 and IID-2). This lower part ends in a $4.5-\mathrm{m}$ interval of low resistivity (Subunit IID-3),

The upper $33 \mathrm{~m}$ of this subunit is characterized by a series of at least six major algal-rich parasequences of increasing shallow-water aspect (Subunits IID-4 through IID-7) (Fig. 4). The overlying Subunit IIC begins with a deepening phase (Fig. 5).

Subunit IID is a full sequence between a basal transgressive surface, followed by transgressive and maximum flooding (Subunits IID-1 to IID-3), and a progressive upward-shallowing succession (Subunits IID-4 to IID-7). The succession is terminated by another transgressive surface (Fig. 5). Relatively sharp upward-shallowing transitions to algal facies at 327.3 and $347.2 \mathrm{mbsf}$ are candidates for "sequence boundaries," although there is no clear link between depth and the occurrence of red algae. Within this overall sequence are numerous parasequence sets. Secondary transgressive/highstand systems tracts with associated flooding and sequence-boundary surfaces appear to be present. This complex suite was assigned as a single subunit by the shipboard sedimentologists, mainly for lack of sufficient core recovery to identify the various facies.

Logging Facies Subunit IID-1

(375.2-387.6 mbsf, $12.4 \mathrm{~m}$ thickness)

Core 144-87IC-27R (374.3-383.7 mbsf, $0.1 \mathrm{~m}$ recovery): lower piece a foraminifer packstone; upper piece a red-algal encrustation 
This unit has a general increase upward to a high natural gamma-ray intensity, with the peak sharply terminated at 375.2 mbsf.

379.2-387.6 mbsf: Low-resistivity interval ending in a 1.4-m-thick, sharptopped, medium-resistivity bed that coincides with a minor peak in uranium concentration.

375.2-379.2 mbsf: Dynamic FMS imagery indicates five subequal alternations of relatively higher and lower resistivities. The gradual increase and uppermost sharp decrease in uranium concentrations within this interval, does not have obvious corresponding features in the FMS imagery, suggesting that some of the uranium concentration may be associated with a redox front, coincident with the higher resistivity base of the next unit.

Interpretation: Basal deepening and deposition of foraminifer packstone was followed by two upward-shallowing successions into algal-rich facies. These parasequences are subdued relative to the underlying Subunit IIE, indicating a relative deepening of the facies. Therefore, this Subunit IID-1 is assigned to a transgressive systems tract. The peak in uranium concentration is a combination of an algal-facies and a redox contrast to the overlying next phase of transgressive flooding, which may have had a higher organic content.

Logging Facies Subunit IID-2

(358.2-375.2 mbsf, $17.0 \mathrm{~m}$ thickness)

Core 144-87IC-26R (364.7-374.3 mbsf, $0.1 \mathrm{~m}$ recovery): foraminiferskeletal packstone to wackestone with numerous shell fragments and gastropod molds, white

375.2-358.2 mbsf: This unit of medium-resistivity has a dynamicprocessed FMS texture of ca. 1-cm-diameter, high-resistivity "clasts" in a massive grainstone-packstone host facies. There is very low natural gamma-ray intensity throughout this interval, which suggests that these features are bioclasts or intraclasts rather than algal rhodoliths. There is a sharp lower boundary between this facies and the underlying Subunit IID-1, and the upper boundary was placed at the contact to the overlying low-resistivity facies of Subunit IID-3.

Interpretation: This unit is a bioclast-rich foraminifer packstone to bivalve-gastropod floatstone. There is no natural gamma-ray or core-recovery signature of algal enrichment. Storm-induced winnowing or influx of intraclasts may be present, but such processes did not result in distinct layers. Alternatively, the entire deposit is a stacked set of storm-winnowed deposits. The deposit begins with a transgressive deepening, therefore, is assigned as a transgressive to early highstand systems tract. The lack of significant algal signature, relative to adjacent units, suggest that this interval represents the deepest depositional environment (i.e., maximum flooding) of Subunit IID.

Logging Facies Subunit IID-3

(353.6-358.2 mbsf, $4.6 \mathrm{~m}$ thickness)

Core 144-87IC-25R (355.1-364.7 mbsf, $0.3 \mathrm{~m}$ recovery): lower piece a bivalve-gastropod floatstone; middle piece a red-algal boundstone; upper piece a foraminifer-peloid packstone, pinkish gray

353.6-358.2 mbsf: This unit has a very low-resistivity lithology, with a dynamic FMS texture of grainstone-packstone, interbedded with $10-$ to $20-\mathrm{cm}-$ thick lenses and blocks of high-resistivity. The lower portion of this interval has a relatively increased uranium concentration. The borehole is washed out in this zone. The upper boundary of this unit is gradational to the high-resistivity beds at the base of Subunit IID-4 and could be considered as the lower portion of its lower parasequence.

Interpretation: The logging characteristics and limited core recovery indicate that this interval is poorly cemented foraminifer-pellet grainstone with scattered lenses of red-algal encrustations. This unit is considered to be part of a highstand systems tract because it is transitional to the overlying suite of algal-rich parasequences.

Logging Facies Subunit IID-4

(347.2-353.6 mbsf, $6.4 \mathrm{~m}$ thickness)

Core 144-871C-24R (345.4-355.I mbsf, $0.05 \mathrm{~m}$ recovery): piece of foraminifer wackestone with bivalve and gastropod molds

349.6-353.6 mbsf: Compound parasequence of two upward increases in resistivity. Lower cycle culminates in a $40-\mathrm{cm}$, high-resistivity peak with a sharp upper surface at $351.8 \mathrm{mbsf}$. Second cycle ends in a thicker $(1.4 \mathrm{~m})$, high-resistivity bed, also with a sharp upper surface. The second cycle is associated with a high concentration of uranium.
347.2-349.6 mbsf: Thin, but high-amplitude, parasequence with a very high-resistivity bed in the upper half that is associated with a high concentration of uranium.

Interpretation: These are a set of thin, upward-shallowing parasequences in algal- or cyanobacterial-rich facies. The very high resistivity of the uppermost bed implies a cemented horizon, which may have been an emergent surface. The subunit is a part of a highstand systems tract.

\section{Logging Facies Subunit IID-5}

(340.2-347.2 mbsf, $7.0 \mathrm{~m}$ thickness)

340.2-347.2 mbsf: Parasequence of upward increase in resistivity. The very high natural gamma-ray intensity includes three secondary peaks in uranium concentration. The FMS imagery indicates thin, discontinuous, highresistivity beds interbedded with a relatively lower resistivity, grainstone-packstone texture.

Interpretation: This is an algal- or cyanobacterial-rich facies, possibly with algal mats, and appears to have three thin parasequences within a main parasequence set. This facies overlies a cemented surface on the underlying subunit, which is tentatively assigned as a minor "sequence boundary" (rapid upward-shallowing episode). Therefore, this unit was deposited during an interval of falling relative sea level or stillstand at a "lowstand" of eustatic sea level, but within a larger sequence framework. The sharp upper surface to a non-algal facies is considered to be a transgressive deepening event.

Logging Facies Subunit IID-6 (333.6-340.2 mbsf, $6.6 \mathrm{~m}$ thickness)

Core 144-87IC-23R (335.8-345.4 mbsf, $0.5 \mathrm{~m}$ recovery): foraminifer wackestone to grainstone; top piece a grainstone of red algae, coral fragments, and foraminifers

333.6-340.2 mbsf: This unit is characterized by low to medium resistivity and low natural gamma-ray intensity. However, the appearance in the FMS imagery is similar to the lower portion of the underlying unit with a low-resistivity grainstone-packstone texture containing scattered, higher resistivity, 5to 10 -cm-thick lenses and $\sim 1-\mathrm{cm}$ spheres of higher resistivity.

Interpretation: This foraminifer-skeletal packstone has subordinate algal accumulations. This interval is a deeper facies than the adjacent units, and represents a brief excursion into a transgressive to early highstand systems tract. The upper portion is transitional into the next set of algal-rich parasequences.

Logging Facies Subunit IID-7

(320.3-333.6 mbsf, $13.3 \mathrm{~m}$ thickness)

Core 144-871C-22R (326.2-335.8 mbsf, $0.3 \mathrm{~m}$ recovery): foraminifer packstone-grainstone and coral-algal-foraminifer packstone

Core 144-871C-21R (316.5-326.2 mbsf, $1.4 \mathrm{~m}$ recovery): algal grainstone in lower part; predominantly coral-gastropod rudstone and foraminifer grainstone in upper part

This interval has four parasequences of low-medium resistivity changing upward to high resistivity. Major peaks of uranium content correlate with the high-resistivity beds. The dynamic FMS imagery indicates a combination of laminated algal mats and grainstone to rudstone beds.

331.5-333.6 mbsf: First parasequence, capped by a 50-cm-thick, very high-resistivity bed with a sharp top. This first parasequence is comparatively algal-poor relative to the overlying parasequences.

327.3-331.5 mbsf: This second cycle may be a compound parasequence because there are two separate sharp-topped high-resistivity beds in the upper $2 \mathrm{~m}$.

325.4-327.3 mbsf: This third cycle also has a two-parasequence character.

320.3-325.4 mbsf: Fourth parasequence cycle (Fig. 5) is a thick episode with a lower resistivity basal portion relative to the underlying parasequences. The upper portion is a cluster of very high-resistivity beds interbedded with medium-resistivity lithology. Sharp top.

Interpretation: Algal-flat facies with several upward-shallowing episodes. This facies is assigned as a highstand systems tract to possible onset of falling eustatic sea level. A possible minor sequence boundary (maximum rate of relative sea-level fall) is placed at $331.5 \mathrm{mbsf}$, where a pronounced highresistivity cemented bed caps the lowest algal-poor parasequence; this interval may represent the most rapid rate of upward shallowing of facies. 
Lithologic Subunit IIC

Composite of Lithologies, Dominated by Foraminifer

Packstone-wackestone

(182.9-320.3 mbsf, $137.4 \mathrm{~m}$ thickness, early and middle Eocene)

\section{Summary of Logging Facies}

The thick lithologic Subunit IIC encompasses a complex suite of vertical successions of facies. The poor recovery of cored intervals, coupled with a bias toward recovery of moderately cemented packstone-wackestone facies, has placed two complete deepening-shallowing cycles and a third deepening event into a single unit. The lagoonal facies (Subunits IIC-2, IIC-3, IIC-5, IIC-7, and IIC-8) consists of a foraminifer-gastropod wackestone-packstone with variable frequencies of storm beds of packstone-grainstone to rudstone (Fig. 6). Shallower facies are algal-coral-enriched parasequences (Subunit IIC-1, upper Subunit IIC-6) or intervals of storm-winnowed debris (Fig. 7) (Subunit IIC-4, lower Subunit IIC-6).

In general, Subunit IIC is significantly more "lagoonal" in character than the underlying algal-rich subunits. The deepening event that initiates this subunit (Fig. 4) appears to coincide with the Paleocene/Eocene boundary, as indicated by the few pieces recovered in Cores 144-871C-20R and -21R. A sea-level rise at the end of the Paleocene may have triggered a more rapid upward growth of the outer coral-algal reef, with the associated formation of a true atoll with inner lagoon. Before this sea-level rise, the center of the Limalok platform appears to have been a shallow bank with extensive algal flats or a current-swept, grainstone-packstone floor.

Logging Facies Subunit IIC-1

(302.4-320.3 mbsf, $17.9 \mathrm{~m}$ thickness)

Core 144-871C-20R (306.9-316.5 mbsf, $0.2 \mathrm{~m}$ recovery): foraminifer packstone with coral fragments

This unit is distinguished by its moderate concentration of uranium, in fact, the top boundary is assigned at a decrease in average resistivity coincident with the termination of this uranium enrichment. There are at least two internal cycles or parasequences of upward-increasing resistivity.

313.6-320.6 mbsf: The basal $4 \mathrm{~m}$ is homogeneous (Fig. 5) with a "rhodolith" or oncoid-bearing grainstone appearance in the dynamic FMS imagery and with an increase in average resistivity in the upper meter. After a $1-\mathrm{m}$ interval of medium resistivity with a grainstone-packstone texture, there is a 1.5 -m high-resistivity zone comprised of a cluster of thin, discontinuous, high-resistivity, lenticular beds. Uranium peaks are associated with the intervals of higher resistivity.

302.4-313.6 mbsf: The lower $6 \mathrm{~m}$ are of medium resistivity, with an upward increase in abundance of high-resistivity, 5- to 10-cm-diameter "clasts" or "rhodolith-like" spherical features. The upper $3 \mathrm{~m}$ is a mixture of high-resistivity lenses in a granular matrix with the same ball-like features. The upper half of this cycle has several overlapping peaks of high natural gamma-ray intensity. The top surface is a sharp contact to a very low-resistivity lithology.

Interpretation: There are two successions of a rhodolith- or oncoid-rich grainstone-packstone shallowing upward to an algal-cyanobacterial mat or algal-flat facies. The unit represents a partial return to the shallow-water algal facies of the underlying Subunit IID, which is terminated by a rapid deepening. The uranium enrichment is associated with the abundance of algae, which may be partially enhanced at the contact to the overlying unit by a redox front.

Logging Facies Subunit IIC-2

(276.4-302.4 mbsf, $26.0 \mathrm{~m}$ thickness)

Core 144-87IC-19R (297.2-306.9 mbsf, $0.1 \mathrm{~m}$ recovery): foraminifer to bivalve-gastropod wackestone

Core 144-871C-18R (287.5-297.2 mbsf, no recovery)

Core 144-871C-17R (278.1-287.5 mbsf, $0.3 \mathrm{~m}$ recovery): foraminifergastropod wackestone; "chalky" appearance

276.4-302.4 mbsf: This medium-resistivity unit contains 30-to 50-cm-thick horizons of higher resistivity that are spaced approximately every 2 to $3 \mathrm{~m}$ (Fig. 6). Natural gamma-ray intensity remains low. The dynamic FMS imagery suggests that the higher resistivity beds are within episodes of increased accumulation of rudstone-type facies. The host facies of foraminifer packstonewackestone has a slightly higher resistivity in the upper half of the unit.

Interpretation: The few pieces of core recovery indicate that this is a lagoonal facies of foraminifer-gastropod packstone-wackestone, in contrast to the underlying unit of algal-rich grainstone. Therefore, the lower boundary at 302.4 mbsf represents a major transgressive deepening. Within the lagoonal muds are several storm-winnowed accumulations of coarser bioclasts or rudstone (Fig. 6). This unit represents the formation of an effective "atoll" structure, with a semiprotected lagoon, in contrast to the algal-flat facies of the lower carbonate platform.

Logging Facies Subunit IIC-3

(248.0-276.4 mbsf, $28.4 \mathrm{~m}$ thickness)

Core 144-87IC-16R (268.8-278.1 mbsf, $0.2 \mathrm{~m}$ recovery): foraminifer wackestone with bivalve and gastropod molds

Core 144-87IC-15R (259.2-268.8 mbsf, $0.2 \mathrm{~m}$ recovery): packstone with mollusk and gastropod molds

Core 144-87IC-14R (249.5-259.2 mbsf, $0.2 \mathrm{~m}$ recovery): foraminifer packstone with mollusk molds; "chalky" appearance

248.0-276.4 mbsf: This unit has very low resistivity with a general packstone-grainstone FMS texture. The dynamic FMS imagery suggests that 40 -cm-thick beds of slightly higher resistivity are spaced about every $1 \mathrm{~m}$, but these events are very subdued relative to those of the underlying Subunit IIC-2. The borehole diameter is widened, and the contacts of just two pads of the FMS tool indicate that the borehole is slanted to the southwest (the pads contact on just the northeast side).

Interpretation: This unit is a lagoonal foraminifer packstone-wackestone. The interval corresponds approximately to a zone of micritized sediments with a "chalky" appearance and with dissolution of all gastropod and bivalve shells. Storm-winnowed deposits are subdued, suggesting a quieter (deeper) setting than in the underlying unit. The onset of this facies is relatively sudden, so a second phase of deepening is associated with the lower boundary at $276.4 \mathrm{mbsf}$.

Logging Facies Subunit IIC-4

(235.0-248.0 mbsf, $13.0 \mathrm{~m}$ thickness)

Core 144-871C-13R (239.8-249.5 mbsf, $0.1 \mathrm{~m}$ recovery): foraminifer packstone with mollusk molds

235.0-248.0 mbsf: This unit is defined by a set of four major "debris" or rudstone beds. In the dynamic FMS imagery, these beds have concentrations of high-resistivity 2- to 5-cm-diameter "clasts" within a granular-texture matrix (Fig. 7). The thickness and center of these beds are $1.2 \mathrm{~m}$ at $247.4 \mathrm{mbsf}$, $0.4 \mathrm{~m}$ at $244.9 \mathrm{mbsf}, 4.9 \mathrm{~m}$ at $240.0 \mathrm{mbsf}$, and $30 \mathrm{~cm}$ at $235.2 \mathrm{mbsf}$. The episodes have sharp bounding surfaces, which are especially pronounced resistivity contrasts for the two thinner beds. Only the second bed has a minor peak in natural gamma-ray intensity. The sediment interbedded between these coarse-clast beds is grainstone-packstone, similar to the underlying unit.

Interpretation: The low natural gamma-ray intensity for these events supports the interpretation that these episodes are concentrations of coarse bioclasts or rudstone, presumably concentrated or redeposited by storm activity. The host sediment is a foraminifer packstone, similar to that of Subunit IIC-3. Unfortunately, the only core recovery within this $13-\mathrm{m}$ interval was apparently $10 \mathrm{~cm}$ of the lagoonal host sediment. The concentration of stormrudstone in this interval indicates a more shallow lagoon relative to the underlying facies. Therefore, the onset of this unit may be a minor sequence boundary. The overlying subunit is a return to "quiet" lagoonal conditions; therefore, the sharp upper boundary of this Subunit IIC-4 is a minor transgressive surface. The interpreted minor sequence boundary at the base may correspond to the Ilerdian/Cuisian boundary according to microfauna indications.

Logging Facies Subunit IIC-5 (223.5-235.0 mbsf, $11.5 \mathrm{~m}$ thickness)

Core 144-871C-12R (230.1-239.8 mbsf, $0.1 \mathrm{~m}$ recovery): foraminiferskeletal wackestone

Core 144-87IC-11R (220.5-230.1 mbsf, $0.1 \mathrm{~m}$ recovery): foraminiferpeloid packstone

223.5-235.0 mbsf: This interval of low-resistivity facies and widened borehole has a grainstone to packstone texture in the FMS imagery, with scattered small (1- to 2-cm-diameter) "clasts" of relatively higher resistivity. There are no significant accumulations of "rudstone."

Interpretation: This is a "quiet" lagoonal deposit of foraminifer-peloid packstone-wackestone. 
Logging Facies Subunit IIC-6

(209.8-223.5 mbsf, $13.7 \mathrm{~m}$ thickness)

Core 144-87IC-10R (210.9-220.5 mbsf, $0.1 \mathrm{~m}$ recovery): foraminifer wackestone with gastropod, coral, and bivalve molds

209.8-223.5 mbsf: A lower set of three "debris" beds is separated from an uppermost 1.8-m-thick, high-resistivity bed by a 5.4-m interval of low resistivity. The lower debris beds generally have relatively sharp upper surfaces and interbeds of typical "lagoonal" sediments similar to the underlying subunit. The low-resistivity interval is also of "lagoonal" grainstone-packstone with a few scattered, high-resistivity, 5-cm-diameter "clasts." The upper high-resistivity interval has an "algal" or oncolite-bearing appearance of high-resistivity lenses in a lower resistivity matrix, and is associated with a set of peaks of high natural gamma-ray intensity.

Interpretation: Subunit IIC-6 consists of three depositional facies. The lower interval is a storm-winnowed, debris-rich facies similar to Subunit IIC-4. It is separated from an upper algal-or cyanobacterial-rich facies by a temporary return to "quiet" lagoonal sediments. The upper algal-facies is sharply overlain by another episode of "quiet" lagoonal facies, indicating a transgressive deepening event. Therefore, the abrupt base of the lower cluster of stormwinnowed or redeposited debris beds could represent a minor "sequence boundary," marking a relative sea-level fall.

Logging Facies Subunit IIC-7

(187.9-209.8 mbsf, $21.9 \mathrm{~m}$ thickness)

Core 144-87IC-9R (201.2-210.9 mbsf, $0.4 \mathrm{~m}$ recovery): foraminifer wackestone-packstone with gastropod and bivalve molds; also includes a piece of dense mudstone with borings

Core 144-871C-8R (191.5-201.2 mbsf, $0.2 \mathrm{~m}$ recovery): foraminifer wackestone with bivalves and gastropods

187.2-209.7 mbsf: Low-resistivity interval of widened borehole conditions. Low natural gamma-ray intensity, except for a pronounced peak at the top of this unit. The texture in the FMS imagery varies from a granular packstonegrainstone to a mottled wackestone-packstone, and there are scattered highresistivity "blocks" up to $10 \mathrm{~cm}$ in diameter. The uppermost $8 \mathrm{~m}$ have a higher average resistivity in the geophysics log and a vague indication of "rubble" on the FMS imagery, but the FMS pads were not able to contact the borehole walls in this extra-widened zone, indicating that this particular facies was not very coherent. The top of the unit is a high-resistivity bed, coinciding with the peak in uranium concentration, and is overlain by another "lagoon" episode.

Interpretation: This is a lagoonal foraminifer packstone-grainstone, possibly containing scattered large bioclasts or concretions. The core recovery of a piece of dense-cemented lime-mud may represent one of these high-resistivity blocks. No distinct storm beds were noted. The uppermost $8 \mathrm{~m}$ may be loosely cemented beds of storm-winnowed debris, implying an upward-shallowing episode. The uranium concentration may be caused by a redox front to the overlying "quiet" lagoon facies.

Logging Facies Subunit IIC-8

(182.9-187.9 mbsf, $5.0 \mathrm{~m}$ thickness)

Core 144-871C-7R (181.9-191.5 mbsf, $0.05 \mathrm{~m}$ recovery): piece of foraminifer packstone

182.9-187.9 mbsf: Highest episode of "quiet" lagoonal foraminifer wackestone-packstone facies. Homogeneous texture similar to underlying episodes. No storm-bed layers. Top of unit is placed at base of lowest high-resistivity storm bed, characteristic of the lower portion of Subunit IIB.

\section{Lithologic Subunit IIB \\ Foraminifer Wackestone to Skeletal Grainstone \\ (161.7-182.9 mbsf, $21.2 \mathrm{~m}$ thickness, middle Eocene)}

\section{Summary of Logging Facies}

Lithologic Subunit IIB was defined by the shipboard sedimentologists as consisting predominantly of grainstone texture, in contrast to the underlying wackestone-packstone facies. The logging characteristics are a high frequency of "storm beds" in the lower portion (Subunit IIB-1), and upward-shallowing parasequences, which include an algal-cyanobacterial component, in the upper portion (Subunit IIB-2). Subunit IIB appears to end abruptly in a sustained algal-cyanobacterial-rich facies (high uranium concentration).

The shipboard distinction of lithologic Subunit IIB is largely an artifact of sparse core recovery that was biased toward the moderately cemented grain- stones. In many respects, Subunit IIB-1 is the culmination of the underlying Subunit IIC lagoonal facies, whereas Subunit IIB-2 displays a distinct upwardshallowing trend (Fig. 8) that leads to the overlying facies of Subunit IIA-1 with possible microbial mats. However, for consistency, we have retained the shipboard lithologic subunits.

The change from a "quiet" lagoon in the underlying Subunit IIC-8 into storm-dominated conditions within Subunit IIB-1 suggests an upwardshallowing episode. Another upward-shallowing episode is at the onset of the algal-rich parasequences in Subunit IIB-2, which display an overall shallowing trend that culminates in an exposure surface at the top of the unit (Fig. 8). The top exposure surface is tentatively assigned as a "sequence boundary." The overlying facies (Subunit IIA-1), rich in algal-cyanobacteria (microbial mats?) may be equivalent to "lowstand" facies on margins with a slower subsidence rate.

Logging Facies Subunit IIB-1

(169.6-182.9 mbsf, $13.3 \mathrm{~m}$ thickness)

Core 144-87IC-6R (172.3-181.9 mbsf, $0.5 \mathrm{~m}$ recovery): foraminifer wackestone with gastropod molds, and foraminifer-skeletal grainstone

181.0-182.9 mbsf: This interval contains four high-resistivity beds. Each is 10 to $15 \mathrm{~cm}$ thick and has sharp upper and lower contacts to "typical lagoon" FMS facies. These beds are probably storm beds.

178.1-181.0 mbsf: A 40-cm "rudstone-debris" bed of high resistivity overlies a low-resistivity interval. The "rudstone-debris" layer has a distinct, but irregular, basal contact and a sharp upper contact.

169.6-178.1 mbsf: The lower $3 \mathrm{~m}$ shows a progressive upward increase in average resistivity, which is mainly the result of an increasing concentration of high-resistivity "clasts." The succession is sharply overlain by a mediumresistivity facies with a mottled "wackestone-packstone" appearance and scattered high-resistivity "clasts" in the FMS imagery, and with a minor peak in uranium concentration in its lower portion.

Interpretation: This interval contains varying concentrations of stormwinnowed or redeposited bioclastic debris. Core recovery indicates interbedded lagoonal foraminifer-gastropod packstone-wackestone and winnowed grainstone. The uppermost few meters may contain some algal-cyanobacterial encrustations. The coarse "debris" beds were probably not recovered.

Logging Facies Subunit IIB-2

(161.7-169.6 mbsf, $7.9 \mathrm{~m}$ thickness)

Core 144-87IC-5R (162.6-172.3 mbsf, $0.05 \mathrm{~m}$ recovery): foraminifer packstone with ostracode and gastropod molds; well cemented but with a highly leached outer surface on one piece

168.2-169.6 mbsf: A basal, 30-cm, high-resistivity layer and the overlying meter of interbedded low-resistivity matrix with thin high-resistivity lenses coincide with a pronounced peak in natural gamma-ray intensity.

163.3-168.2 mbsf: Moderate natural gamma-ray intensity continues through two cycles of medium-resistivity homogeneous "granular" facies overlain by a $0.6-$ or a $1.0-\mathrm{m}$-thick band, respectively, of stacked high-resistivity lenses (Fig. 8). The uppermost high-resistivity band has a sharp upper surface.

161.7-163.3 mbsf: This interval contains two $15-\mathrm{cm}$-thick, sharpbounded, high-resistivity layers, but the main facies is low-resistivity lithology and displays a mottled "packstone-wackestone" texture in the FMS imagery.

Interpretation: A horizon of algal-cyanobacterial encrustation (microbial mat?) is overlain by winnowed foraminifer grainstone interbedded with other algal-encrustation episodes. A progressive upward reduction of uranium concentration within the upper $1-\mathrm{m}$, well-cemented, algal-cyanobacterialencrustation episode suggests a possible emergence horizon (oxidative leaching associated with subaerial exposure). Emergence is also suggested by the recovery of a well-cemented packstone piece that had experienced leaching on its surface. This algal-rich interval is followed by a brief return to lagoonal conditions with storm layers.

\section{Lithologic Subunit IIA \\ Foraminifer Packstone-wackestone \\ (139.5-161.7 mbsf, $22.2 \mathrm{~m}$ thickness, middle Eocene)}

\section{Summary of Logging Facies}

Lithologic Subunit IIA is a composite of depositional environments in rapid succession. The lower $9 \mathrm{~m}$ are interbedded, high-resistivity algal mats 
and low-resistivity grainstone with a high uranium concentration (Subunit IIA-1). A lagoonal packstone-wackestone interval (Subunit IIA-2) precedes a final interval of algal-cyanobacterial-rich facies (Subunit IIA-3), capped by a cemented phosphate-rich bed of "lagoonal" packstone-wackestone (Subunit IIA-4) (Fig. 9). The drowning of the carbonate platform at this site begins with the transgressive surface at the top of the algal-cyanobacterial-rich facies of Subunit IIA-3, and the final Subunit IIA-4 represents a partially preserved, deeper water facies that accumulated during the drowning.

Logging Facies Subunit IIA-1

(152.9-161.7 mbsf, $8.8 \mathrm{~m}$ thickness)

Core 144-871C-4R (152.9-162.6 mbsf. $0.5 \mathrm{~m}$ recovery): foraminiferpeloid wackestone-packstone; lower portion is foraminifer-intraclast grainstone with keystone vugs

152.9-161.7 mbsf: A low-resistivity "packstone-grainstone" matrix contains bands of variable concentrations of high-resistivity lenses. Peaks in uranium concentration coincide with the greater abundance of these lenses. The higher resistivity top of this unit coincides with a decrease in natural gamma-ray intensity and is sharply overlain by a lagoonal facies.

Interpretation: This zone has algal-encrusted lenses or microbial mats within a foraminifer-peloid-intraclast packstone-grainstone matrix. In contrast to the periodic well-cemented layers of underlying Subunit IIB-2, this algal-cyanobacterial-rich interval does not appear to have experienced possible episodes of emergence; however, the keystone vugs in one piece of recovered foraminifer grainstone suggests an intertidal depositional environment. The periodic algalcyanobacteria concentrations might indicate a stacked suite of upward-shallowing cycles during an interval of slow accommodation rate (falling sea level partially cancelling subsidence). Therefore, this facies is tentatively correlated to a falling or lowstand of eustatic sea level (although it is not represented by a "lowstand systems tract") and is terminated by a transgressive deepening.

Logging Facies Subunit IIA-2

(147.0-152.9 mbsf, $5.9 \mathrm{~m}$ thickness)

Core 144-87IC-3R (143.3-152.9 mbsf, $0.2 \mathrm{~m}$ recovery): foraminifer packstone with coral and bivalve molds

147.0-152.9 mbsf: The host sediment has a diffuse mottled "packstonegrainstone" texture in the FMS imagery and a low natural gamma-ray intensity. Cycle of medium-to-low to medium-resistivity corresponds to changing concentration of 1-to 2-cm-diameter high-resistivity "clasts." The unit has a sharp upward transition to the overlying algal-cyanobacterial-rich unit.
Interpretation: This unit has identical characteristics to typical "lagoonal" foraminifer packstone-grainstone sediments of lower lagoon episodes. It is a transgressive to highstand systems tract relative to adjacent units.

Logging Facies Subunit IIA-3
140.8-147.0 mbsf, $6.2 \mathrm{~m}$ thickness)

142.9-147.0 mbsf: This facies is similar to Subunit IIA-1, with bands of variable concentrations of 5- to 15-cm-thick, high-resistivity lenses or discontinuous layers within a "granular" host sediment (Fig. 9). The uranium concentration mirrors the abundance of the high-resistivity lenses. This interval ends in an 80-cm band of higher resistivity with a sharp upper surface.

140.8-142.9 mbsf: This 2-m layer of very low resistivity contains scattered high-resistivity lenses and displays a peak in uranium concentration.

Interpretation: Subunit IIA-3 is an algal-cyanobacterial-rich facies of encrustations or microbial mats interbedded with packstone or low-resistivity grainstone (Fig. 9). The upper 2-m band may have experienced partial dissolution. This algal-cyanobacterial-rich facies suggests an upward shallowing from the underlying lagoonal facies. The interval ends in a deepening event.

$$
\text { Logging Facies Subunit IIA-4 }
$$$$
\text { (139.5-140.8 mbsf, } 1.3 \mathrm{~m} \text { thickness) }
$$

Core 144-87IC-2R (133.7-143.3 mbsf, $0.6 \mathrm{~m}$ recovery): $\mathrm{Fe}-\mathrm{Mn}$ and phosphatic crusts on foraminifer wackestone-packstone

Core 144-87IC-IR (124.0-133.7 mbsf, no recovery)

139.5-140.8 mbsf: Very high-resistivity layer with a "lagoonal" texture in the dynamic FMS imagery (1- to 2-cm-diameter spots of higher resistivity in a grainstone-packstone sediment; Fig. 9). This layer corresponds to a pronounced peak in uranium concentration. There is a very sharp contact to the overlying very low-resistivity facies (Unit I of pelagic sediment).

Interpretation: There is no FMS-textural evidence for algal features: therefore, the high uranium concentration is considered to be associated with the phosphatic enrichment observed in the recovered pieces in this interval. The final facies preserved before drowning of the carbonate platform is a lagoonal-type sediment; however, this episode may represent last-stage sediment accumulation during the early stages of drowning. The actual drowning probably began at the top of the underlying algal-rich Subunit IIA-3. Indeed, this final bed may be post-drowning redeposited sediment that was later cemented upon further deepening below the wave base. The sharp upper surface of this cemented bed is probably a partial artifact of post-drowning, bottom-erosion, rather than an original truncation to sediment accumulation. 